\section{Bath Spa University}

Newton St Loe, Bath, BA2 9BN, United Kingdom.

Website: www.bathspa.ac.uk

Bath Spa University's vision is to be a leading educational institution in creativity, culture and enterprise. Through innovative teaching and research, the University provides a high quality student experience. Based in a world heritage city and connected to a network of international partners, Bath Spa University ensures that its graduates are socially engaged global citizens.

\section{International Partner Scholarship}

Purpose: Bath Spa University's International Partner Scholarships celebrate our strong partnerships with leading universities across the world

Eligibility: Open to postgraduate taught Master's applicants from Bath Spa University partner institutions. Applications are welcome from international students who have completed undergraduate or postgraduate education at a partner institution; achieved high academic results; can demonstrate experience in university, community and society activities; can show future aspirations to become involved in university life at Bath Spa University; plus show ideas on how Bath Spa University can work with its partner institutions towards promoting global citizenship.

Type: Scholarship

Value: $£ 3,000$

Frequency: Annual

Application Procedure: Applications are made through the international scholarship application form. Applicants must hold an offer of admission for a Bath Spa University postgraduate taught degree programme that is full-time and taught on-campus, be a graduate of a Bath Spa University partner institution, and complete the International Scholarship Application Form

Additional Information: For further information, please check at www.bathspa.ac.uk/international-students/scholar ships/international-partner-scholarship

\section{For further information contact:}

Email: international@bathspa.ac.uk

\section{Invertimos en el talento de los Colombianos (ICETEX) Artistas Jovenes Scholarships}

Purpose: ICETEX's Artistas Jovenes Talentos programme is a unique programme that supports young Colombian artists and designers, filmmakers, performers and musicians, writers and poets. As the leading United Kingdom university for partner of ICETEX, and the top United Kingdom creative university, the ICETEX Artistas Jovenes Talentos is a perfect fit for applicants to Bath Spa University's programmes across art, design, film, writing, music and performance

Eligibility: Applications are open for candidates who meet the requirements of ICETEX application process. Full details of eligibility are available on the ICETEX website

Level of Study: Graduate, Postgraduate

Type: Scholarship

Application Procedure: (i) Eligible candidates must first have an offer of admission for the chosen programme, If you meet the entry criteria for the chosen course you will be sent a conditional offer of admission by email. You must meet all the academic conditions of offer, including submission of certificates and transcripts, translated copies, English Language requirement, passport copy, references. (ii) Once you have received an offer letter to the chosen programme of study you then complete the ICETEX Artistas Jovenes Talentos process 
Additional Information: Bath Spa University can provide individual help and advice on your application and has a dedicated office in Colombia

\section{For further information contact:}

Bath Spa University, Newton Park, Newton St Loe Bath, BA2 9BN, United Kingdom.

Tel: $\quad$ (44) 13003710

Email: BSUColombia@bathspa.ac.uk

\section{Invertimos en el Talento de los Colombianos (ICETEX) Scholarships}

Purpose: The University of Salford is pleased to work with ICETEX to offer funding opportunities for Colombian students to study in the United Kingdom

Eligibility: Applications are open for candidates who meet the requirements of ICETEX application process. Full details of eligibility are available on the ICETEX website at

Type: Scholarship

Value: $50 \%$ tuition fee

Frequency: Annual

Country of Study: Any country

Application Procedure: Applicants must apply for the programme of study and then the scholarship via ICETEX. Applicants must also submit a completed Bath Spa University International Scholarship Application form and include the ICETEX reference number. Further application details are given in the website

Closing Date: 10 May

Funding: Private

Additional Information: Applications will be reviewed on submission of the relevant documentation to ICETEX and the Bath Spa University Application Form. The applications are reviewed within two weeks after the deadline by the University Committee. For further information, refer the website link below. beta.salford.ac.uk/international/icetex-scholarshipscolombia

\section{Latin America - Creative and Culture Scholarships}

Purpose: Bath Spa University is the United Kingdom's leading university for creativity, culture and enterprise. To celebrate this excellence, and to support Bath Spa University's work in Latin America

Eligibility: Applicants must be nationals from Latin America who have applied for and hold an offer for any of the eligible programmes, have high academic results and can demonstrate a commitment to creativity, culture and enterprise in Latin America

Level of Study: Graduate, Postgraduate

Type: Scholarship

Value: $£ 5,000$ off tuition fees for your first year of study (two available)

Application Procedure: Please complete all the details, including your name, contact details, student number and qualifications. Applications with missing details will be automatically rejected. If you're awaiting your final results, you're still able to apply. Please state 'pending results' in the qualification section. You must submit your results when they're available. The scholarship essay question is very important. To answer this question you should include details that cover all the criteria: Academic achievement / results Involvement in activities at your previous university, community work and your contribution to society, Charity / volunteer work you've done, Information on your future aspirations, Examples on how you'll contribute to the social and economic development of your country. You should also give examples on how you intend to become involved in university life at Bath Spa. Closing Date: 31 May

Additional Information: Applications are reviewed on submission of the International Scholarship Application Form. Particular attention is given to the scholarship essay. The applications are reviewed in the month after the deadline by the University Committee www.bathspa.ac.uk/students/studentfinance/scholarships-and-funding/scholarships-latin-america/

\section{For further information contact:}

Tel: $\quad$ (44) 1225875777

Email: international@bathspa.ac.uk

\section{Postgraduate Overseas Scholarship}

Eligibility: Open to applicants who have met the required entry qualification and been offered a place (conditional or unconditional) on a postgraduate taught Masters' programme. It is awarded on the basis of academic merit

Type: Scholarship

Value: $£ 1,000$

Application Procedure: Eligibility for the Overseas Scholarship is judged on the basis of the application to the chosen programme of study. There is no need to submit a separate application form. If you are selected for a Postgraduate Overseas Scholarship you will receive a confirmation letter at the time of your offer of admission

\section{For further information contact:}

Tel: (44) 1225875777

Email: international@bathspa.ac.uk 


\section{Vice Chancellor's International Scholarship}

Purpose: The Bath Spa University Vice Chancellor's International Scholarship celebrates our commitment to internationalization and excellence in creativity, culture and enterprise

Eligibility: Applications are welcome from international students who have achieved high academic results and can demonstrate a commitment to creativity, culture and enterprise

Level of Study: Graduate, Postgraduate

Type: Scholarship

Value: $£ 5,000$

Application Procedure: Applicants must hold an offer of admission for a Bath Spa University postgraduate taught Master's degree programme that is full-time and taught on-campus, and complete the International Scholarship Application Form. Please complete all the details, including your name, contact details, student number and qualifications. Applications with missing details will be automatically rejected

Closing Date: 30 June

Additional Information: Please check details at www. bathspa.ac.uk/international-students/scholarships/vice-chance llors-international-scholarship

\section{For further information contact:}

Tel: (44) 1225875777

Email: international@bathspa.ac.uk

\section{Bayer AG}

Werk Leverkusen, D-51368 Leverkusen, Germany.

Tel: $\quad$ (49) 2143026672

Email: gisela.dambach.gd@bayer-ag.de

Website: www.aspirin.com

Contact: Gisela Dambach, International Aspirin Award

\section{Bayer Foundation Scholarships}

Purpose: Bayer Foundation supports students aspiring to study in Germany with five fellowship programmes in biology, medical science, agricultural science, non-academic professions, and chemistry

Eligibility: The project to be supported must be innovative and international. 1. Scholarships are granted to students and young professionals (up to 2 years after graduation) German student wishing to realize a study or research project abroad or Foreign students pursuing a project in Germany. 2. An innovative project plan. All applicants should have a high level of commitment, dedication and an innovative project plan. Scholarships are granted to students and young professionals (up to two years after graduation) from Germany wishing to realize a study or research project abroad or to foreign students/young professionals pursuing a project in Germany

Level of Study: Graduate

Type: Research grant

Value: Approximately $€ 6,400$ per year up to 2 years after graduation

Frequency: Annual

Country of Study: Any country

Application Procedure: The Bayer Science \& Education Foundation supports students and young professionals that would like to study or work outside of their home country with the Bayer Foundation Fellowship Program, which consists of five scholarships. All applicants should have a high level of commitment, dedication and an innovative project plan. Scholarships are granted to students and young professionals (up to two years after graduation) from Germany wishing to realize a study or research project abroad or to foreign students/young professionals pursuing a project in Germany

Closing Date: 18 July

Funding: Private

For further information contact:

Email: info@global-opportunities.net

\section{Bayreuth International Graduate School of African Studies (BIGSAS)}

University of Bayreuth, D-95440 Bayreuth, Germany.

Email:_bigsas@uni-bayreuth.de

Contact: BIGSAS

The University of Bayreuth is a hub of international and interdisciplinary research. African Studies have been a priority at the University of Bayreuth since its foundation in 1975. The Bayreuth International Graduate School of African Studies (BIGSAS) brings together African and European academic networks and fosters partnership.

\section{Bayreuth International Graduate School of African Studies Sandwich Scholarship Programme}

Eligibility: Applicants must have a very good Master's Degree in one of the disciplines represented at the Graduate 
School. Applications may be sent in German, English or French; the working language of BIGSAS is English

Level of Study: Doctorate

Type: Programme grant

Value: $€ 1,200$ monthly

Length of Study: 3 years

Frequency: Annual

Study Establishment: The Bayreuth International Graduate School of African Studies

Country of Study: Germany

Application Procedure: For more information on your online application please refer to: www.bigsas.uni-bayreuth. de/en/phd_programme/application/index.html

Closing Date: 28 February

Contributor: German Research Foundation of the Excellence Initiative of the German Federal and State Governments Additional Information: scholarship-fellowship.com/ bigsas-sandwich-scholarship/

\section{For further information contact:}

Email:_bigsas-application@uni-bayreuth.de

\section{Beinecke Scholarship Program}

Box 125, Fogelsville, PA 18051-0125, United States of America.

\section{Tel: $\quad$ (1) 6103955560}

Email:_BeineckeScholarship@earthlink.net

Website: www.beineckescholarship.org

Contact: Dr Thomas L. Parkinson, Program director

The Beinecke Scholarship Program, established in 1970, seeks to encourage and enable highly motivated students to take the fullest advantage of graduate opportunities available to them and be courageous in the selection of graduate study programmes.

\section{Beinecke Scholarship}

Purpose: Established by the Board of Directors of The Sperry and Hutchinson Company, the Beinecke Scholarship Program awards substantial scholarships to students to support their graduate education in the arts, humanities and social sciences at any accredited institution.

Eligibility: junior at the time of application

Level of Study: Postgraduate

Type: Scholarship
Value: US $\$ 34,000$

Length of Study: $1-5$ years

Study Establishment: Any accredited university

Application Procedure: Request and submit a completed application form a curriculum vitae, a personal statement of 1,000 words and three letters of recommendation from faculty members

Closing Date: 12 February

Funding: Corporation

Contributor: The Sperry and Hutchinson Company

Additional Information: www.nyu.edu/academics/awardsand-highlights/global-awards/scholarships/beinecke-scholar ship-program.html

\section{For further information contact:}

Email: scholarships@nyu.edu

\section{Beit Trust (Zimbabwe, Zambia and Malawi)}

PO Box CH 76, Chisipite, Harare, Zimbabwe.

Tel:

$$
\text { (263) } 4496132
$$

Email:_beitrust@africaonline.co.zw

Website: www.beittrust.org.uk

\section{Beit Trust Postgraduate Scholarships}

Purpose: To support postgraduate study or research Eligibility: Open to persons under 30 years of age or 35 years for medical doctors, who are university graduates domiciled in Zambia, Zimbabwe or Malawi. Applicants must be nationals of those countries

Level of Study: Postgraduate

Type: Scholarship

Value: Fees and costs of tuition and related academic expenses are paid by the Trust direct to the universities. Payment of a personal allowance, index linked in accordance with guidance from an independent authority covering maintenance support. Other allowances are paid for arrival, a laptop and printing of a thesis, and return home. Economy Class air passages are provided by the Trust for the initial journey to the place of study, and for the return at the end of the course

Length of Study: A maximum of 3 years depending on course sought

Frequency: Annual

Study Establishment: Approved universities and other institutions in South Africa, Britain and Ireland 
Application Procedure: Applicants must complete an application form

No. of awards offered: 400

Closing Date: 12 February

Funding: Private

No. of awards given last year: 8

No. of applicants last year: 400

Additional Information: Zambian applicants should contact the BEIT Trust United Kingdom office. Zimbabwe and Malawi applicants should contact the Zimbabwe office beittrust.org.uk/beit-trust-scholarships

\section{For further information contact:}

The BEIT Trust, BEIT House, Grove Road, Woking, Surrey, GU21 5JB, United Kingdom.

Tel: (44) 1483772575

Fax: (44) 1483725833

Email: africa@beittrust.org.uk

\section{Belgian American Educational Foundation (B.A.E.F.)}

195 Church Street, New Haven, NH, 06510 United States of America.

Email: $\quad$ Emile.Boulpaep@Yale.edu

Website: www.baef.us

Contact: Belgian American Educational Foundation, Inc

\section{Belgian American Educational Foundation (B.A.E.F.)}

Purpose: For fellowships for advanced study or research Eligibility: Applicants must be citizens or permanent residents of the United States. Knowledge of Dutch, or French, or German is optional

Type: Fellowship

Value: US\$27,000 for Master

Length of Study: 1 year

Frequency: Annual

Country of Study: Any country

Application Procedure: Application forms can be downloaded from the B.A.E.F. website at: www.baef.us

Closing Date: 31 October

Additional Information: For additional information contact the Foundation at the above address or email: Emile. Boulpaep@Yale.edu www.baef.be/documents/fellowships-forbelgian-citizens/initial-master-degree-in-the-usa1.xml?lang=en
For further information contact:

Email: mail@baef.be

\section{Fellowships for study of research in Belgium}

Purpose: Fellowships for advanced study or research during the academic year, at a Belgian university or institution of higher learning. The fellowships provide outright non-renewable grants carrying a stipend of US\$28,000 for Master's or PhD students US\$32,000 for Post-doctoral Fellows

Eligibility: Applicants must be citizens or permanent residents of the United States. Applicants must 1. Either at the time of application be registered in a $\mathrm{PhD}$ or equivalent degree program in the United States. 2. Or while holding the BAEF fellowship register in a graduate program (Master's or PhD) in Belgium. 3. Or hold a Master's, PhD, or equivalent degree. Post-doctoral applicants should by 1 July have no more than 2 years since obtaining their PhD degree

Level of Study: Doctorate, Graduate, Postdoctorate, Postgraduate, Predoctorate, Professional development, Research, MBA, Postgraduate (MSc)

Type: Ten fellowships

Value: $\$ 28,000$ for Master's or PhD students, $\$ 32,000$ for Post-doctoral Fellows

Length of Study: 12 months in Belgium. If the Fellow chooses to remain less than the full 12 months in Belgium, the stipend will be prorated accordingly. The minimum fellowship period is 6 months

Frequency: Annual

Country of Study: Belgium

Application Procedure: Applicants must be citizens or permanent residents of the United States Applicants must either at the time of application be registered in a $\mathrm{PhD}$ or equivalent degree program in the United States, or while holding the BAEF Fellowship register in a graduate program (Master's or PhD) in Belgium, or hold a Master's, PhD, or equivalent degree. Post-doctoral applicants should by July 1,2020 have no more than 2 years since obtaining their $\mathrm{PhD}$ degree.

No. of awards offered: 40

Closing Date: 1 July

Funding: Foundation

Contributor: Foundation Endowment

No. of awards given last year: 10

No. of applicants last year: 40

Additional Information: Application forms can be downloaded from the B.A.E.F. website at: www.baef.us .www. baef.be/documents/fellowships-for-us-citizens/study-resfellow.-for-us-citizen-.xml?lang=en 


\section{For further information contact:}

Belgian American Educational Foundation, Inc., 195 Church Street, New Haven, CT 06510, United States of America.

Email: emile.boulpaep@yale.edu

\section{Belgian Flemish University, VLIR-UOS}

Website: www.vliruos.be/6323.aspx

\section{VLIR-UOS Training and Masters Scholarships}

Purpose: VLIR-UOS awards scholarships to students from 31 eligible countries in Africa, Asia and Latin-America, to follow an English-taught training or master programme at a Flemish university or university college in Belgium

Eligibility: You can only apply for a scholarship if you meet the following requisites: - Nationality and Country of Residence, A candidate should be a national and resident of one of the 31 countries of the VLIR-UOS country list for scholarships (not necessarily the same country) at the time of application. - Age. The maximum age for a Master programme candidate is 35 years for an initial masters and 40 years for an advanced masters. The candidate cannot succeed this age on January 1 of the intake year. - Professional background and experience, Priority is given to candidates who are employed in academic institutions, research institutes, governments, the social economy or NGOs, or who aim at a career in one of these sectors. However, master candidates employed in the profit sector or newly graduated candidates without any work experience can be eligible for the scholarship as well, depending on their motivation and profile. The training candidate should have relevant professional experience and a support letter confirming (re)integration in a professional context where the acquired knowledge and skills will be immediately applicable.

Level of Study: Postgraduate

Type: Scholarship

Value: VLIR-UOS only provides full scholarships for the total duration of the training or Master

Frequency: Annual

Country of Study: Belgium

Application Procedure: Via the university's website, you will have to apply for both admission to the programme as well as for the scholarship itself. When you apply for the programme, be sure to mention whether you wish to apply for a scholarship. The deadline varies and are determined by the programme but most deadlines are around 1 February or 1 March 2020 for Masters Programmes. The call of applications for training programmes will open at various times and can be monitored at this link. It is important to visit the official website and the websites of the specific Training or Master's Programme you have chosen for detailed information on how to apply for this scholarship.

Closing Date: 1 March

Contributor: Flemish university

Additional Information: For more information, please visit official scholarship website: www.vliruos.be/6323.aspx www.scholars4dev.com/2257/vlir-uos-masters-scholarshipsfor-developing-countries/

\section{For further information contact:}

Email: scholarships@vliruos.be

\section{Belgian Technical Cooperation agency (BTC), Ghent University}

BTC - Belgian Development Agency, Rue Haute, 147, B-1000 Brussels, Belgium.

Tel: $\quad$ (32) 25053700

Website: www.belspo.be/belspo/index_nl.stm

The Belgian Technical Cooperation agency (BTC) is the administrator and coordinator for scholarships awarded by the Belgian Directorate-General for Development Cooperation (DGDC). The BTC itself does not award grants. The BTC's Scholarship Unit implements the scholarship files, welcomes the students and provides them with guidance for the duration of their academic training and stay in Belgium.

\section{Belgian Technical Cooperation Scholarships}

Purpose: The Belgian Technical Cooperation agency (BTC) is the administrator and coordinator for scholarships awarded by the Belgian Directorate-General for Development Cooperation (DGDC). The BTC itself does not award grants. The BTC's Scholarship Unit implements the scholarship files, welcomes the students and provides them with guidance for the duration of their academic training and stay in Belgium.

Eligibility: Candidates from one of the BTC partner countries Level of Study: Postgraduate

Type: Scholarship

Value: The scholarships are awarded primarily to finance third- cycle (postgraduate) courses.

Length of Study: 1 or 2 academic years

Country of Study: Belgium 
Application Procedure: Candidates interested in a scholarship should send their application form directly to the Attaché for Development Cooperation or to the Embassy of Belgium in the partner country

Contributor: Belgian Directorate-General

Additional Information: www.ugent.be/en/research/ funding/devcoop/btc.htm

\section{For further information contact:}

Email: development.cooperation@vub.ac.be

\section{Berkeley Graduate Division}

\section{Conference Travel Grants}

Purpose: Academic master's and all doctoral students may apply for funding to attend professional conferences or to participate in professional development activities

Eligibility: 1. Be registered for the term in which they are planning to attend the conference, which also includes payment of fees/tuitions. Note: students on filing fee are not eligible. 2. Be in good academic standing. 3. Be presenting a paper or poster at the conference.

Level of Study: Postgraduate

Type: Fellowship

Value: (up to US\$600 within California, US\$900 elsewhere in North America, including Canada and Mexico, and US $\$ 1,500$ outside of North America)

Additional Information: grad.berkeley.edu/financial/ fellowships/

\section{For further information contact:}

318 Sproul Hall, Barrow Lane, Berkeley, CA 94704, United States of America.

Tel: (1) 5106420672

\section{Robert E. Thunen Memorial Scholarships}

Purpose: These scholarships are for students who wish to study any and all fields of lighting (such as architectural, commercial, residential, airport, navigational, theatrical or television, agricultural, and vision)

Eligibility: They arrange for at least three letters of recommendation, at least one of which shall be from someone involved with lighting professionally or academically. The Thunen Scholars for each year will be announced in mid-May of each year
Level of Study: Graduate

Type: Scholarship

Value: US $\$ 2,500$

Frequency: Annual

Country of Study: Any country

Application Procedure: Applications and letters of recommendation should be submitted before 1 April of each year

Closing Date: 1 April

Funding: Private

Additional Information: grad.berkeley.edu/news/funding/ robert-thunen-memorial-scholarships/

\section{For further information contact:}

Mary-Jane Lawless Thunen Scholarship Committee, IES San Francisco Section, 1201 Park Ave Ste 100, Emeryville, CA 94608, United States of America.

Email: mlaw@silvermanlight.com

\section{Berlin Graduate School Muslim Cultures and Societies}

Altensteinstrasse 48, D-14195, Berlin, Germany.

Tel: $\quad$ (49) 3083853417

Email: office@bgsmcs.fu-berlin.de

Website: www.fu-berlin.de/en/

\section{Zentrum Moderner Orient and Berlin Graduate School of Muslim Cultures and Societies Visiting Research Fellowship}

Purpose: We are interested in attracting outstanding researchers who are engaged in research projects that are relevant to the respective research profiles at ZMO and BGSMCS

Eligibility: The call is open for senior researchers and recent postdocs in the humanities and the social sciences. Applications by candidates from Africa, Asia and the Middle East are particularly encouraged

Level of Study: Postgraduate

Value: Successful applicants will receive a monthly stipend $(€ 2,500$, covering all expenses including travel and accommodation), and a period of stay that should normally last up to 3 months

Country of Study: Germany

Closing Date: 15 September

Funding: Trusts

Additional Information: mideast.unc.edu/zmo-bgsme/ 


\section{Berlin Mathematical School}

TU Berlin, Sekr. MA 2-2, Strasse des 17. Juni 136, D-10623 Berlin, Germany.

Tel: $\quad$ (49) 3031478611

Email: office@math-berlin.de

Contact: Berlin Mathematical School

The Berlin Mathematical School (BMS) is a joint graduate school of the mathematics departments of the three major Berlin universities, TU Berlin, FU Berlin, and HU Berlin. BMS invite excellent mathematics students from Berlin, Germany, Europe and all over the world to join BMS - and to make good use of the ample opportunities offered by the rich and diverse mathematics teaching and research environment.

\section{Dirichlet International Postdoctoral Fellowship at Berlin Mathematical School in Germany}

Purpose: In 2012 the Berlin Mathematical School (BMS) implemented its Dirichlet Postdoctoral Fellowship Program. This program, advertised widely across the broad range of mathematical fields represented in Berlin, contributed to making the BMS even more visible internationally, and attracted outstanding applications from all around the world. This was evidenced by the many letters of recommendation from very prominent and international mathematicians.

Eligibility: International applicants are eligible to apply for this fellowship. For more details, please check the website

Type: Postdoctoral fellowship

Value: The competitive full-year salary includes health insurance Frequency: Annual

Study Establishment: Fellowship is awarded to young mathematicians who want to pursue their own research in one of the eight research fields of mathematics offered by the Berlin Mathematical School

Country of Study: Germany

Application Procedure: Applications will be accepted via our online portal probably from 1 October to 1 December 2020

Closing Date: 1 December

Additional Information: For more details, please browse the below website. scholarship-positions.com/dirichlet-inter national-postdoctoral-fellowship-berlin-mathematical-schoolgermany www.math-berlin.de/bms-faculty/dirichlet-postdoc toral-program

\section{For further information contact:}

Email: postdoc@math-berlin.de

\section{Beta Phi Mu Headquarters}

PO Box 42139, Philadelphia, PA 19101, United States of America.

Tel: $\quad$ (1) 2673615018

Email: headquarters@betaphimu.org

Website: www.betaphimu.org

Contact: Isabel Gray, Program Director

Beta Phi Mu is a library and information studies honor society, founded in 1948, with over 35,000 graduates of the ALA-initiated accredited professional programmes. Beta Phi $\mathrm{Mu}$ was founded at the University of Illinois

\section{American Library Association Beta Phi Mu Award}

Purpose: This award is given out on an annual basis Eligibility: Library school faculty member or individual Type: Award

Value: US $\$ 1,000$

Frequency: Annual

Country of Study: Any country

Application Procedure: Guidelines and application available on the American Library Association website: www. ala.org/awardsgrants/awards/43/apply

Closing Date: 2 March

Funding: Trusts

Contributor: Beta Phi Mu International Library Science Honorary Society

No. of awards given last year: 1

Additional Information: www.ala.org/awardsgrants/betaphi-mu-award

\section{For further information contact:}

American Library Association 50 East Huron Street, Chicago, IL 60611-2795, United States of America.

Tel: $\quad$ (1) 3129446780

Fax: (1) 3124409374

Email: cmalden@ala.org

\section{Bibliographical Society of America (BSA)}

PO Box 1537, Lenox Hill Station, New York, NY 10021, United States of America.

Tel: $\quad$ (1) 2124522710

Email: bsa@bibsocamer.org 
Website: www.bibsocamer.org

Contact: Ms Michele Randall, Executive Director

The Bibliographical Society of America (BSA) invites applications for its annual short-term fellowships, which supports bibliographical inquiry as well as research in the history of the book trades and in publishing history.

\section{Bibilography Society of America -Harry Ransom Center Pforzheimer Fellowship in Bibliography}

Purpose: Supports the bibliographical study of early modern books and manuscripts, 1455-1700, held in the Ransom Center's Pforzheimer Library and in related collections of early printed books and manuscripts, including the Pforzheimer Gutenberg Bible

Eligibility: For the 2020 Fellowship cycle, eligibility is limited to: US Citizens and Residents, Citizens of other nations without US residency who wish to conduct research outside of the United States only, This is a temporary restriction, and we are working to open our fellowships to all those who wish to apply in the 2021 cycle.

Level of Study: Unrestricted

Type: Fellowship

Value: US $\$ 3,000$

Frequency: Annual

Country of Study: Any country

Application Procedure: Applications should include the following components: Applicant's curriculum vitae, project proposal of no more than 1,000 words, project budget, project timeline, Two letters of recommendation submitted via Kaleidoscope. The committee will not accept letters of recommendation by any other means.

Closing Date: 1 November

Funding: Private

Contributor: BSA-Harry Ransom Center Pforzheimer

Additional Information: www.hrc.utexas.edu/research/fel lowships/bsa/ bibsocamer.org/awards/fellowships/

\section{For further information contact:}

Email: bsafellowships@bibsocamer.org

\section{Justin G. Schiller Prize}

Purpose: The Schiller Prize for Bibliographical Work on pre-twentieth century children's books is intended to encourage scholarship in the bibliography of historical children's books Eligibility: Works put into nomination, which must be in English, may concentrate on any children's book printed before the year 1901 in any country or any language.
Submissions should involve research into bibliography and printing history broadly conceived and should focus on the physical book as historical evidence for studying topics such as the history of book production, publication, distribution, collecting, or reading. Studies of the printing, publishing, and allied trades, as these relate to children's books, are also welcome. Eligible scholarship may take the form of a published book or article, a master's thesis or doctoral dissertation that has been defended and approved, or research results distributed in another manner, such as on a website or a CD-ROM. Eligible scholarship must have been published, approved, or posted between 1 January and 1 October. Nominations, with copies of the monographs or links to articles and websites, must be completed by 15 November

Level of Study: Unrestricted

Type: Prize

Value: US $\$ 3,000$

Frequency: Every 3 years

Study Establishment: pre-twentieth century children's books

Country of Study: Any country

Application Procedure: Applications must contain the following items: a letter of intent addressed to the "Schiller Prize Committee," a one-page curriculum vitae, any documentation regarding the approval of a thesis or a dissertation or confirming the date of a publication, if required. A hard copy of a published monograph or essay placed into nomination is encouraged, but a PDF is acceptable. If a copy is not submitted, a complete citation of the work must be included with the application. Authors of web-based or online resources should provide the URL for the full-text or submit a PDF. Web-based resources require free access to the website and instructions regarding its use, along with a statement regarding plans for maintaining ongoing access

Closing Date: 15 November

Funding: Individuals

Contributor: Endowed by Justin G. Schiller

Additional Information: Please also send an additional applications to this email - aimmel@Princeton.EDU bibsocamer.org/awards/justin-g-shiller-prize/

\section{For further information contact:}

Department of Rare Books and Special Collections, Princeton University Library, 1 Washington Road, Princeton, NJ 085442098, United States of America.

Tel: (1) 6092581470

\section{St. Louis Mercantile Library Prize}

Purpose: Encourage scholarship in the bibliography of American history and literature 
Eligibility: Submissions for the Mercantile Library Prize should concentrate on some aspect of American history and culture in territories that now comprise the United States, or on literature by American authors, or literature intended for publication in territories that now comprise the United States. They should involve research in bibliography and printing history broadly conceived and focus on the book (the physical object) as historical evidence for studying topics such as the history of book production, publication, distribution, collecting, or reading. Studies of the printing, publishing, and allied trades, as these relate to American history and literature, are also welcome. Submissions may take the form of a published book or article, a master's thesis or doctoral dissertation defended and approved, or research results distributed in another manner, such as the website or CD-ROM. Submissions must have been published or, if a dissertation or thesis, approved the year of the deadline or in the three previous calendar years. If a publication has an incorrect nominal date disqualifying it for submission but an actual date of publication within the prize period, it may be nominated with a letter by the publisher or editor testifying to the actual date of publication. Unpublished dissertations and theses must be accompanied by a letter from the director attesting their approval. Scholars are eligible to apply for the Prize without regard to membership in the Bibliographical Society of America or any other society, and without regard to citizenship or academic affiliation, degree, or rank. The Prize will be awarded to the author of a particular work of scholarship without regard to the author's prolonged or repeated contributions to the field. Applications are encouraged from young or junior scholars who have not as yet published extensively. Applicants may nominate themselves or be nominated by others

Level of Study: Doctorate

Type: Prize

Value: US $\$ 2,000$

Frequency: Every 3 years

Study Establishment: Bibliography of American History and Literature

Country of Study: United States of America

Application Procedure: Please send the following as separate PDF or Word (.doc or .docx) files to mercantile. prize@bibsocamer.org

Closing Date: 1 November

Funding: Private

Contributor: St. Louis Mercantile Library at the University of Missouri, St. Louis

Additional Information: If for any reason the cost of securing review copies is prohibitive to submitting a nomination, please contact Erin Schreiner, BSA Executive Director, by email at bsa@bibsocamer.org bibsocamer.org/awards/stlouis-mercantile-library-prize/

\section{The Bibilographic Society of America-Rare Book School Fellowship}

Purpose: The BSA-Rare Book School Fellowship funds tuition for one course for one first-year attendee each year at the University of Virginia's Rare Book School

Eligibility: For the 2020 Fellowship cycle, eligibility is limited to: US Citizens and Residents, Citizens of other nations without US residency who wish to conduct research outside of the United States only, This is a temporary restriction, and we are working to open our fellowships to all those who wish to apply in the 2021 cycle.

Level of Study: Unrestricted

Type: Fellowship

Value: Tuition for 1 course and US\$500 toward travel

Length of Study: 1 year

Frequency: Annual

Country of Study: United States of America

Application Procedure: Applications should include the following components: Applicant's curriculum vitae, Project proposal of no more than 1,000 words, Project budget, Project timeline, Two letters of recommendation submitted via Kaleidoscope. The committee will not accept letters of recommendation by any other means.

Closing Date: 1 November

Funding: Private

Contributor: Rare Book School University of Virgina

Additional Information: Candidates should consult the Rare Book School website and apply as there as directed. bibsocamer.org/awards/st-louis-mercantile-library-prize/

\section{For further information contact:}

Email: bsafellowships@bibsocamer.org

\section{The Bibilographic Society of America Short-term Fellowships}

Purpose: These fellowships support bibliographical research that focuses on the physical aspects of books or manuscripts as historical evidence. Books and manuscripts in any field and of any period are eligible for consideration. Projects may include studying the history of book or manuscript production, publication, distribution, collecting, or reading. Projects to establish a text are also eligible.

Eligibility: For the 2020 Fellowship cycle, eligibility is limited to: US Citizens and Residents, Citizens of other nations without US residency who wish to conduct research outside of the United States only This is a temporary restriction, and we are working to open our fellowships to all those who wish to apply in the 2021 cycle. 
Level of Study: Unrestricted

Type: Fellowship

Value: US $\$ 3,000$

Frequency: Varies

Study Establishment: Bibliographical research that focuses on the physical aspects of books or manuscripts as historical evidence

Country of Study: Any country

Application Procedure: Applications should include the following components: Applicant's curriculum vitae. Project proposal of no more than 1,000 words, Project budget, Project timeline, Two letters of recommendation submitted via Kaleidoscope. The committee will not accept letters of recommendation by any other means.

Closing Date: 1 November

Funding: Foundation

Contributor: The BSA

Additional Information: For more information, please contact Hope Mayo, Chair of the Fellowship Committee at bsafellowships@bibsocamer.org. bibsocamer.org/awards/ fellowships/

\section{For further information contact:}

Email: bsafellowships@bibsocamer.org

\section{The Bibliographical Society of America - American Society for Eighteenth-Century Studies Fellowship for Bibliographical Studies in the Eighteenth Century}

Purpose: Recipients must be a member of the American Society for Eighteenth-Century Studies at the time of the award

Eligibility: For the 2020 Fellowship cycle, eligibility is limited to: US Citizens and Residents, Citizens of other nations without US residency who wish to conduct research outside of the United States only, This is a temporary restriction, and we are working to open our fellowships to all those who wish to apply in the 2021 cycle.

Type: Fellowship

Value: US $\$ 3,000$

Frequency: Annual

Country of Study: Any country

Application Procedure: Applications should include the following components: Applicant's curriculum vitae, Project proposal of no more than 1,000 words, Project budget, Project timeline, Two letters of recommendation submitted via Kaleidoscope. The committee will not accept letters of recommendation by any other means.

Closing Date: 1 November
Funding: Private

Contributor: American Society for Eighteenth-Century Studies

Additional Information: For more information, please contact Hope Mayo, Chair of the Fellowship Committee at bsafellowships@bibsocamer.org. bibsocamer.org/awards/ fellowships/

\section{For further information contact:}

Email: bsafellowships@bibsocamer.org

\section{The Bibliographical Society of America - Pine Tree Foundation Fellowship in Culinary Bibliography}

Purpose: Supports the bibliographical study of printed and manuscript cookbooks (once commonly known as receipt books); medical recipe books that also contain culinary recipes; other types of books, manuscript, and printed material that include a substantial body of culinary recipes; treatises on and studies of gastronomy; or memoirs, diary accounts, or descriptions of food and cooking. Projects may cover any period or country

Eligibility: US Citizens and Residents Citizens of other nations without US residency who wish to conduct research outside of the United States only This is a temporary restriction, and we are working to open our fellowships to all those who wish to apply in the 2021 cycle.

Level of Study: Unrestricted

Type: Fellowship

Value: US $\$ 3,000$

Frequency: Annual

Country of Study: Any country

Application Procedure: Applications should include the following components: Applicant's curriculum vitae, Project proposal of no more than 1,000 words, Project budget, Project timeline, Two letters of recommendation submitted via Kaleidoscope. The committee will not accept letters of recommendation by any other means.

Closing Date: 1 November

Funding: Foundation

Contributor: BSA-Pine Tree Foundation

Additional Information: Links to the new Fellowship Application form will be available by 1 August. The application package and two supporting letters of recommendation must be received by 1 November. We regret that we cannot consider late or incomplete applications. Applicants are advised to request recommendation letters well in advance. For more information, please contact Hope Mayo, Chair of the Fellowship Committee at bsafellowships@bibsocamer.org bibsocamer.org/awards/fellowships/ 


\section{For further information contact:}

Email: bsafellowships@bibsocamer.org

\section{The Bibliographical Society of America - Pine Tree Foundation Fellowship in Hispanic Bibliography}

Purpose: Supports the bibliographical study of printed and manuscript items 1) in the Spanish language produced during any period and in any country; or 2) in any language provided they were produced in Spain, or in its overseas dominions during the time of Spanish sovereignty; or 3) the bibliographical study of book and manuscript collections in Spain, or in its overseas dominions during the time of Spanish sovereignty; or 4) the bibliographical study of Spanish-language book and manuscript collections during any period and in any country

Eligibility: US Citizens and Residents Citizens of other nations without US residency who wish to conduct research outside of the United States only This is a temporary restriction, and we are working to open our fellowships to all those who wish to apply in the 2021 cycle.

Level of Study: Unrestricted

Type: Fellowship

Value: US\$3,000

Frequency: Annual

Country of Study: Any country

Application Procedure: Applications should include the following components: Applicant's curriculum vitae, Project proposal of no more than 1,000 words, Project budget, Project timeline, Two letters of recommendation submitted via Kaleidoscope. The committee will not accept letters of recommendation by any other means.

Closing Date: 1 November

Funding: Foundation

Contributor: BSA- Pine Tree Foundation

Additional Information: Links to the new Fellowship Application form will be available by 1 August. The application package and two supporting letters of recommendation must be received by 1 November. We regret that we cannot consider late or incomplete applications. Applicants are advised to request recommendation letters well in advance. For more information, please contact Hope Mayo, Chair of the Fellowship Committee at bsafellowships@bibsocamer.org bibsocamer.org/awards/ fellowships/

\section{For further information contact:}

Email: bsafellowships@bibsocamer.org

\section{The Bibliographical Society of America - St. Louis Mercantile Library Fellowship}

Purpose: Supports research in North American bibliography, including studies in the North American book trade, production and distribution of North American Books, North American book illustration and design, North American collecting and connoisseurship, and North American bibliographical history in general. Non-traditional and innovative projects will be especially welcome and encouraged

Eligibility: US Citizens and Residents Citizens of other nations without US residency who wish to conduct research outside of the United States only This is a temporary restriction, and we are working to open our fellowships to all those who wish to apply in the 2021 cycle.

Level of Study: Unrestricted

Type: Fellowship

Value: US $\$ 3,000$

Frequency: Annual

Country of Study: Any country

Application Procedure: Applications should include the following components: Applicant's curriculum vitae, Project proposal of no more than 1,000 words, Project budget, Project timeline, Two letters of recommendation submitted via Kaleidoscope. The committee will not accept letters of recommendation by any other means.

Closing Date: 1 November

Funding: Private

Contributor: St. Louis Mercantile Library

Additional Information: Links to the new Fellowship Application form will be available by 1 August. The application package and two supporting letters of recommendation must be received by 1 November. We regret that we cannot consider late or incomplete applications. Applicants are advised to request recommendation letters well in advance. For more information, please contact Hope Mayo, Chair of the Fellowship Committee at bsafellowships@bibsocamer.org bibsocamer.org/awards/fellowships/

\section{For further information contact:}

Email: bsafellowships@bibsocamer.org

\section{The Charles J. Tanenbaum Fellowship in Cartographical Bibliography}

Purpose: Supports projects dealing with all aspects of the history, presentation, printing, design, distribution and reception of cartographical documents from Renaissance times to 
the present, with a special emphasis on eighteenth-century cartography

Eligibility: US Citizens and Residents Citizens of other nations without US residency who wish to conduct research outside of the United States only This is a temporary restriction, and we are working to open our fellowships to all those who wish to apply in the 2021 cycle.

Level of Study: Unrestricted

Type: Fellowship

Value: US $\$ 3,000$

Frequency: Annual

Country of Study: Any country

Application Procedure: Applications should include the following components: Applicant's curriculum vitae, Project proposal of no more than 1,000 words, Project budget, Project timeline, Two letters of recommendation submitted via Kaleidoscope. The committee will not accept letters of recommendation by any other means.

Closing Date: 1 November

Funding: Foundation

Contributor: Pine Tree Foundation of New York

Additional Information: Links to the new Fellowship Application form will be available by 1 August. The application package and two supporting letters of recommendation must be received by 1 November. We regret that we cannot consider late or incomplete applications. Applicants are advised to request recommendation letters well in advance. For more information, please contact Hope Mayo, Chair of the Fellowship Committee at bsafellowships@bibsocamer.org bibsocamer.org/awards/fellowships/

\section{For further information contact:}

Email: bsafellowships@bibsocamer.org

\section{The Fredson Bowers Award}

Purpose: Major grant funded jointly with the Bibliographical Society of the UK

Eligibility: US Citizens and Residents Citizens of other nations without US residency who wish to conduct research outside of the United States only This is a temporary restriction, and we are working to open our fellowships to all those who wish to apply in the 2021 cycle.

Level of Study: Unrestricted

Type: Bursary

Value: $£ 1,500$

Frequency: Annual

Country of Study: United Kingdom or United States of America
Application Procedure: Applications for the Pantzer Fellowship and for major grants (including the Pantzer Scholarship) must be submitted, on the appropriate form (with no additional documentation). Two referees familiar with the applicant's work should be asked to email references to the Secretary to the Fellowships and Bursaries Sub-committee

Closing Date: 6 January

Funding: Private

Contributor: Bibliographical Society of America and Bibliographical Society of the United Kingdom

Additional Information: United Kingdom entries should follow application instructions located at this website www. bibsoc.org.uk/fellowships/application-procedure bibsocamer. org/awards/fellowships/

\section{For further information contact:}

Email: acrd2002@aol.com

\section{The Katharine F. Pantzer Senior Fellowship in the British Book Trades}

Purpose: To support the mission of the Society to foster the study of books and other textual artifacts in traditional and emerging formats, and in keeping with the value which the Society places on the field of bibliography as a critical interpretative framework for understanding such artifacts, the BSA funds a number of fellowships designed to promote bibliographical inquiry and research.

Eligibility: Supports research by a senior scholar engaged in bibliographical inquiry into the history of the book trades and publishing history in Britain during the hand-press period, as well as studies of authorship, reading and collecting based on the examination of British books published in that period, with a special emphasis on descriptive bibliography

Type: Fellowship

Value: US $\$ 6,000$

Frequency: Varies

Study Establishment: Bibliographical research of the British Book Trades

Country of Study: Any country

Application Procedure: Applications are due 1 November of each year. Applications should include the following components: Application form; project proposal of no more than 1,000 words; Applicant's curriculum vitae; two signed letters of recommendation on official letterhead submitted independently by referees. The two letters of recommendation must be signed and submitted independently by referees (in PDF or MS Word format) via the BSA Fellowship recommendation submission form. No other documentation will be considered 
by the committee. - Please visit the website to download the form. The fellowship committee will match proposed projects to suitable fellowships, and the awards will be announced at the annual meeting of the Society in January of each year. All fellowships require a project report within one year of receipt of the award, and copies of any publications resulting from the project are to be sent to the BSA. Links to the new Fellowship Application form will be available by 1 August. The application package and two supporting letters of recommendation must be received by 1 November. We regret that we cannot consider late or incomplete applications. Applicants are advised to request recommendation letters well in advance. For more information, please contact Hope Mayo, Chair of the Fellowship Committee at bsafellowships@ bibsocamer.org

Closing Date: 1 November

Funding: Individuals

Contributor: Katherine Panzer

Additional Information: Links to the new Fellowship Application form will be available by 1 August. The application package and two supporting letters of recommendation must be received by 1 November. We regret that we cannot consider late or incomplete applications. Applicants are advised to request recommendation letters well in advance. For more information, please contact Hope Mayo, Chair of the Fellowship Committee at bsafellowships@bibsocamer.org bibsocamer.org/awards/fellowships/

\section{The Katharine Pantzer Junior Fellowship in the British Book Trades}

Purpose: Supports bibliographical inquiry into the history of the book trades and publishing history in Britain during the hand-press period, as well as studies of authorship, reading and collecting based on the examination of British books published in that period, with a special emphasis on descriptive bibliography

Eligibility: Supports bibliographical inquiry into the history of the book trades and publishing history in Britain during the hand-press period, as well as studies of authorship, reading and collecting based on the examination of British books published in that period, with a special emphasis on descriptive bibliography

Level of Study: Unrestricted

Type: Fellowship

Value: US $\$ 3,000$

Frequency: Annual

Country of Study: Any country

Application Procedure: Applications are due 1 November of each year. Applications should include the following components: Application form; projectproposal of no more than 1,000 words; Applicant's curriculum vitae; two signed letters of recommendation on official letterhead submitted independently by referees. The two letters of recommendation must be signed and submitted independently by referees (in PDF or MS Word format) via the BSA Fellowship recommendation submission form. No other documentation will be considered by the committee. Please visit the website to download the form. The fellowship committee will match proposed projects to suitable fellowships, and the awards will be announced at the annual meeting of the Society in January of each year. All fellowships require a project report within one year of receipt of the award, and copies of any publications resulting from the project are to be sent to the BSA. Links to the new Fellowship Application form will be available by 1 August. The application package and two supporting letters of recommendation must be received by 1 November. We regret that we cannot consider late or incomplete applications. Applicants are advised to request recommendation letters well in advance. For more information, please contact Hope Mayo, Chair of the Fellowship Committee at bsafellowships@ bibsocamer.org

Closing Date: 1 November

Funding: Individuals

Contributor: Katherine Panzer

Additional Information: Links to the new Fellowship Application form will be available by 1 August. The application package and two supporting letters of recommendation must be received by 1 November. We regret that we cannot consider late or incomplete applications. Applicants are advised to request recommendation letters well in advance. For more information, please contact Hope Mayo, Chair of the Fellowship Committee at bsafellowships@bibsocamer.org bibsocamer.org/awards/fellowships/

\section{The Reese Fellowship for American Bibliography and the History of the Book in the Americas}

Purpose: The fellowship may be awarded to any scholar, whether academic or independent, whose project explores the history of print culture in the Western Hemisphere

Eligibility: The fellowship may be awarded to any scholar, whether academic or independent, whose project explores the history of print culture in the Western Hemisphere

Level of Study: Unrestricted

Type: Fellowship

Value: US\$3,000

Frequency: Annual

Country of Study: Any country

Application Procedure: Applications are due 1 November of each year. Applications should include the following components: Application form Project proposal of no more than 1,000 words Applicant's curriculum vitae Two signed letters of recommendation on official letterhead submitted 
independently by referees. The two letters of recommendation must be signed and submitted independently by referees (in PDF or MS Word format) via the BSA Fellowship recommendation submission form. No other documentation will be considered by the committee. The fellowship committee will match proposed projects to suitable fellowships, and the awards will be announced at the annual meeting of the Society in January of each year. All fellowships require a project report within one year of receipt of the award, and copies of any publications resulting from the project are to be sent to the BSA. Links to the new Fellowship Application form will be available by 1 August. The application package and two supporting letters of recommendation must be received by 1 November. We regret that we cannot consider late or incomplete applications. Applicants are advised to request recommendation letters well in advance. For more information, please contact Hope Mayo, Chair of the Fellowship Committee at bsafellowships@bibsocamer.org

Closing Date: 1 November

Funding: Corporation

Contributor: William Reese Company

Additional Information: Links to the new Fellowship Application form will be available by 01 August. The application package and two supporting letters of recommendation must be received by 1 November. We regret that we cannot consider late or incomplete applications. Applicants are advised to request recommendation letters well in advance. For more information, please contact Hope Mayo, Chair of the Fellowship Committee at bsafellowships@bibsocamer.org bibsocamer.org/awards/fellowships/

\section{Bielefeld University}

Bielefeld Graduate School in History and Sociology, Postfach 1001 31, D-33501 Bielefeld, Germany.

Tel: $\quad$ (49) 5211066526

Email:_bghs@uni-bielefeld.de

Website: www.uni-bielefeld.de/bghs

\section{Bielefeld Graduate School in History and Sociology Start-up Doctoral Scholarships}

Purpose: The Bielefeld Graduate School in History and Sociology is inviting applications for six scholarships for international prospective doctoral researchers starting in 1 April

Eligibility: Applicants should hold a Master's degree or equivalent in sociology, history, political science, social anthropology or gender studies; applications from related disciplines are welcome. The university strongly encourages women to apply. Graduates from abroad who wish to pursue a doctoral degree in history, sociology, anthropology or political science may apply for a start-up scholarship. We welcome applications from predoctoral researchers. Applicants should speak either German or English fluently

Level of Study: Doctorate, Postgraduate

Type: Scholarship

Value: A stipend of GE€1,200 per month. This amount will be supplemented by an allowance for children if applicable. Upon application, travel costs can also be covered by the Graduate School

Length of Study: 4 months

Frequency: Annual

Study Establishment: University of Bielefeld

Country of Study: Germany

Application Procedure: Applications should be submitted online (www.uni-bielefeld.de/(en)/bghs/bewerbung/startup/ start-up.html)

Closing Date: 31 July

Contributor: University of Bielefeld

Additional Information: www.uni-bielefeld.de/(en)/bghs/ neu/Ausschreibungen/startup_scholarships.html

\section{Bilkent University}

Faculty of Business Administration, MBA Programme, Office of the Dean, TR-06800 Ankara, Turkey.

Tel: $\quad$ (90) 3122901596

Email: fba@bilkent.edu.tr

Website: www.bilkent.edu.tr

Contact: MBA Admissions Officer

Bilkent University is a non-profit research university. Courses are conducted in English. The University has more than 11,000 students and an international teaching staff of 1,000 .

\section{Bilkent Industrial Engineering Fellowship}

Level of Study: Doctorate

\section{For further information contact:}

Bilkent University Department of Industrial Engineering, Main Campus Engineering Building Floor 3, Bilkent, TR06800 Ankara, Turkey.

Tel: $\quad$ (90) 3122901262

Fax: (90) 3122664054

Email: barbaros@bilkent.edu.tr 


\section{Bilkent International Relations Fellowship}

Purpose: To develop skills in international political analysis Eligibility: Candidates are selected on the basis of past academic achievement and references

Level of Study: Doctorate

Type: Fellowship

Value: A monthly stipend and a tuition waiver

Frequency: Annual

Study Establishment: Bilkent University

Country of Study: Turkey

Application Procedure: Contact the Department of International Relations

\section{For further information contact:}

Tel: $\quad$ (90) 3122664195

Fax: (90) 3122664326

Email: ir@bilkent.edu.tr

\section{Bilkent Mathematics Fellowship}

Eligibility: Preference is given to research proposals focused on non-linear differential equations and general relativity

Level of Study: Doctorate, Postdoctorate

Type: Fellowship

Value: A monthly stipend and a tuition fee waiver

Frequency: Annual

Study Establishment: Bilkent University

Country of Study: Turkey

Application Procedure: Contact the department

\section{For further information contact:}

Tel: $\quad$ (90) 3122664377

Fax: (90) 3122664579

Email: kocatepe@fen.bilkent.edu.tr

\section{Bilkent MIAPP Fellowship}

Purpose: To fund International and European affairs and executives who, understand and can deal with the increasing complex problems of a rapidly changing world

Level of Study: Doctorate, Postdoctorate

Type: Fellowship

Value: A monthly stipend and a tuition fee waiver

Length of Study: 2 year

Frequency: Annual

Study Establishment: Bilkent University

Country of Study: Turkey

Application Procedure: Contact the Department
Additional Information: w3.bilkent.edu.tr/bilkent/gradstud ents/master-of-international-affairs-and-public-policy/

For further information contact:

Tel: $\quad$ (90) 3122901249

Fax: (90) 3122664960

Email: muge@bilkent.edu.tr

\section{Bilkent Political Science Fellowship}

Purpose: To provide a sophisticated conceptual framework and the analytical skills to specialize in a particular aspect of Turkish or comparative politics

Eligibility: Applicants are required to have an MA degree in Political Science, Public Administrator or International Relations

Level of Study: Doctorate

Type: Fellowship

Value: A monthly stipend and a tuition fee waiver

Frequency: Annual

Study Establishment: Bilkent University

Country of Study: Turkey

Application Procedure: Contact the department

For further information contact:

Tel: $\quad$ (90) 3122901931

Fax: (90) 3122902792

Email: cindoglu@bilkent.edu.tr

\section{Bilkent Turkish Literature Fellowship}

Purpose: To enhance the standards of Turkish literary studies and universalize the field

Eligibility: Candidates will be required to take written and/or oral exams to prove their competence in Turkish, Ottoman and English

Level of Study: Doctorate

Type: Fellowship

Value: A monthly stipend and a tuition fee waiver

Length of Study: 3 years

Frequency: Annual

Study Establishment: Bilkent University

Country of Study: Turkey

Application Procedure: Contact the department

For further information contact:

Tel: $\quad$ (90) 3122902711

Fax: (90) 3122664059

Email: turkedeb@bilkent.edu.tr 


\section{Biola University}

The Financial Aid Office, 13800 Biola Avenue, La Mirada, CA 90639, United States of America.

Tel: $\quad$ (1) 5629034742

Email: finaid@biola.edu

Website: www.biola.edu

Contact: Financial Aid Officer

\section{Church Matching Scholarship}

Purpose: Biola-funded match to church sponsorship

Eligibility: Students must meet the following eligibility requirements: Student must be enrolled at least half-time, Student must be enrolled in a traditional degree program. Student must demonstrate financial need based on FAFSA information. Student must receive financial sponsorship from a church. Special programs are not eligible.

Level of Study: Graduate

Type: Scholarship

Value: Up to US $\$ 1,300$ per year

Length of Study: 1 year

Frequency: Annual

Country of Study: Any country

Application Procedure: Completed FAFSA (Biola listed), Complete the Church Matching Scholarship application, Church sponsorship check should be written out to Biola University and attached to the Church Matching Scholarship Application

Closing Date: 2 October

Funding: Private

Additional Information: This scholarship is not renewable. Student must reapply annually based on financial need and additional church sponsorship www.biola.edu/financial-aid/ scholarships-and-aid/undergrad/biola- scholarships

\section{For further information contact:}

13800 Biola Ave. La Mirada, CA 90639, United States of America.

Tel: $\quad$ (1) 5629036000

Email: business@biola.edu

\section{Biomedical Engineering Society (BMES)}

\section{Career Development Awards}

Subjects: Biomedical Engineering
Purpose: BMES is committed to inclusive excellence in building pathways to biomedical engineering careers and developing a diverse, technically and globally competent biomedical workforce. To that end, BMES has an award category to support travel to the BMES Annual Meeting for Graduate Students, Postdoctoral Fellows, and Early Career Professionals from underrepresented populations in biomedical engineering and/or involved in research and training focused on health disparities and minority health.Â.

Eligibility: Applicant must be: A Graduate Student, Postdoctoral Fellow, or Early Career Professional at a critical transition or re-entry point in their career from an underrepresented population that includes racial and ethnic minorities and/or involved in research or training focused on health disparities or minority health. Early Career Professional is defined as a junior professional, junior faculty, and young investigators who received a degree in biomedical engineering or a related science within three (3) years of the date of application. Groups identified as underrepresented in science and engineering include; Women, African Americans, Alaskan Natives, Hispanics, American Indians/Native Americans, and Pacific Islanders (Guam, Hawaii and American Samoa). A BMES Member in good standing who has not received BMES funding to attend the 2019 BMES Annual Meeting through any other BMES source.

Type: Award

Value: The award recipients will receive a complimentary registration to attend the meeting and a stipend in the amount of US\$599 to assist with travel expenses to and from the meeting.

Country of Study: Any country

Additional Information: www.bmes.org/content.asp? $\operatorname{admin}=\mathrm{Y} \&$ contentid $=594$

\section{Diversity Lecture Award}

Subjects: Biomedical Engineering

Purpose: The BMES Diversity Award honors an individual, project, organization, or institution for outstanding contributions to improving gender and racial diversity in biomedical engineering. The award is given for a broad range of activities, including research, education, and service improving diversity in the biomedical engineering industry and/or academia. The award seeks to recognize lifetime achievements as well as innovative and/or high impact activities. Â.

Eligibility: The nominee must be an individual, project, or organization/institution demonstrating outstanding contributions to improving gender and racial diversity in biomedical engineering. The nominee is not required to be a BMES member. The award recipient (individual or representative of the project or organization/institution) is expected to accept the award in person and deliver a 20-minute lecture at the 2020 BMES Annual Meeting in San Diego, California. The 
recipient is expected to publish an article regarding aspects of the works recognized by the award in the Annals of Biomedical Engineering.

Type: Award

Value: This award consists of US $\$ 1,000$ check, a crystal plaque, complimentary registration for the BMES Annual Meeting (for the individual or project/organization/institution)

Frequency: Annual

Country of Study: Any country

Application Procedure: The application, including CV and Nomination Summary on letterhead (not to exceed 3 pages), must be submitted by May 15 .

Closing Date: 15 May

Additional Information: www.bmes.org/content.asp? $\operatorname{admin}=$ Y\&contentid $=593$

\section{Robert A. Pritzker Distinguished Lecture Award}

Subjects: Biomedical Engineering

Purpose: This prestigious award is given each year to recognize an individual's outstanding achievements and leadership in the science and practice of biomedical engineering.

Eligibility: The award recipient may have achieved excellence in biomedical engineering by contributions within the setting of the university, industry, or government. The awardee's contributions are not required to precede the award date by any specific period of time. Applicants must be a member of BMES in good standing.

Type: Award

Value: This recipient receives complimentary registration for the Annual Meeting, a crystal plaque, an honorarium of US\$12,000 and travel expenses up to US\$1,250.

Frequency: Annual

Country of Study: Any country

Application Procedure: Please complete the application form along with a letter describing the nominee's service to biomedical engineering, the nominee's Curriculum Vitae, and letter(s) of support (not to exceed 5 letters).

Closing Date: 15 May

Additional Information: www.bmes.org/content.asp? $\operatorname{admin}=$ Y\&contentid $=597$

\section{Biotechnology and Biological Sciences Research Council (BBSRC)}

Polaris House, North Star Avenue, Swindon, Wiltshire SN2 1UH, United Kingdom.

Tel: $\quad$ (44) 1793413200

Email:_postdoc.fellowships@bbsrc.ac.uk

Website: www.bbsrc.ac.uk
BBSRC is the United Kingdom's principal funder of basic and strategic biological research. It is a non-departmental public body, one of the seven Research Councils supported through the Science and Innovation Group of the Department for Innovation, Universities and Skills (DIUS). It supports research and research training in universities and research centres throughout the United Kingdom, including BBSRCsponsored institutes, and promotes knowledge transfer from research to applications in business, industry and policy, and public engagement in the biosciences. It funds research in some exciting areas including genomics, stem cell biology, and bionanotechnology.

\section{David Phillips Fellowships}

Purpose: The David Phillips Fellowship (DPF) provides support for researchers wishing to establish their first independent research group

Eligibility: DPF applicants are not eligible to apply to any additional 2020 BBSRC fellowship competitions or to the UK Research and Innovation Future Leaders Fellowship call in the same calendar year. Please see the Fellowship Handbook for further details on eligibility criteria.

Level of Study: Postdoctorate

Type: Fellowship

Value: value of up to $£ 1$ million $(80 \% \mathrm{fEC})$

Length of Study: 5 years

Application Procedure: Applicants should have considered their training needs (as detailed in the Career Development Plan), and the research environment should be supportive and the best place for the applicant to carry out their research project and advance their career.

Closing Date: 12 May

Additional Information: Fellowships are awarded under full economic costing (fEC). Further queries, please contact Postgraduate Training and Research Career Development Branch. Important: applicants should ensure proposals are submitted to their host institution's Je-S submitter/approval pool well in advance (a minimum of 5 working days) of the published deadline bbsrc.ukri.org/funding/filter/david-phillips/

\section{For further information contact:}

Email: postdoc.fellowships@bbsrc.ukri.org

\section{Institute Career Path Fellowships}

Eligibility: Open to candidates who have a minimum of 3 years and no more than 10 years of active postdoctoral research experience

Level of Study: Doctorate, Postdoctorate 


\section{For further information contact:}

Email: fiona.tomley@bbsrc.ac.uk

\section{Institute Development Fellowships}

Purpose: To enable BBSRC scientists to spend a period of collaborative work at another research organization and to provide a mechanism for the influx of new ideas and new skills in strategically important areas to enhance the quality of science in BBSRC sponsored institutes

Eligibility: Open to all BBSRC scientists at Band 5 and above on an open-ended contract, who have worked for a minimum of 5 years in their current or similar post

Level of Study: Research

Type: Fellowships

Value: To cover the costs associated with the proposed research development activities

Length of Study: 6-12 months

Application Procedure: All applications must be submitted online

Closing Date: 14 November

Additional Information: Further queries, please contact Postgraduate Training and Research Career Development Branch

\section{Professorial Fellowships}

Purpose: To support world-class scientists with a proven track record of developing new and innovative directions of research and who have the potential to use a fellowship to open up dramatic and novel lines of work

Eligibility: Open to scientists who are already recognized at an international level as outstanding researchers with exceptional research and interpretative achievements

Type: Fellowships

Value: Grant to cover the costs of the research programme

Length of Study: 5 years

Application Procedure: Check website for further details

Closing Date: 14 November

Additional Information: Further queries, please contact Postgraduate Training and Research Career Development Branch

\section{Research Development Fellowships}

Purpose: To support scientists wishing to undertake new directions in their research. Applicants seeking to develop interdisciplinary dimensions by integrating new techniques or methodologies into their research are particularly encouraged Eligibility: Open to scientists who are full-time members of academic staff of a United Kingdom university who have worked for a minimum of 5 years in their current or similar post
Type: Fellowship

Value: To cover the costs associated with the proposed research development activities

Length of Study: 1-3 years

Application Procedure: Applications must be submitted online

Closing Date: 14 November

Additional Information: Further queries, please contact Postgraduate Training and Research Career Development Branch

\section{Birkbeck, University of London}

Malet Street, Bloomsbury WC1E 7HX, United Kingdom.

Birkbeck, University of London, is a public research university located in Bloomsbury, London, United Kingdom, and a constituent college of the federal University of London

\section{Birkbeck International Merit Scholarships}

Eligibility: Birkbeck is offering a number of merit scholarships to suitably qualified students from Japan, Russia, South Korea, Turkey, Latin America, South-East Asia (ASEAN) and Taiwan. Accepted International Student by the University; Excellent Academic and Leadership Achievements

Type: Scholarship

Value: Scholarship amount: $£ 2,500-£ 5,000$

Country of Study: United Kingdom

Application Procedure: 1. Initially, you will have to apply to Birkbeck, University of London. 2. Once you have received an offer from Birkbeck, you must email them an essay of no more than 500 words. The essay should detail why you are the ideal candidate to receive the International Merit Scholarship. Recipients will be chosen based on a combination of academic merit and financial need

Closing Date: 1 June

Additional Information: scholarship-positions.com/fullyfunded-birkbeck-postgraduate-scholarships-international-stud ents-uk/2017/11/15/

\section{For further information contact:}

Email: international-office@bbk.ac.uk

\section{Bonnart Trust PhD Scholarship}

Purpose: The scholarship will be awarded to an outstanding candidate whose research topic explores a theme concerned 
with either 'diversity and belonging' or 'minorities and social justice'

Eligibility: You should usually have an upper second-class undergraduate honours degree, or equivalent, and a Master's degree, or equivalent. You will need to be an outstanding candidate whose research topic explores a theme concerned with either diversity and belonging or minorities and social justice. We encourage applications from candidates who are able to draw connections between their doctoral research and contemporary concerns and practical outcomes beyond the university. We will only consider current Birkbeck students who are already enrolled on an MPhil/PhD degree within the School of Social Sciences, History and Philosophy under exceptional circumstances.

Type: Scholarship and award

Value: $£ 1,000$ per scholar

Frequency: Every 3 years

Country of Study: Any country

Application Procedure: For further information, check the following website. www.bbk.ac.uk/sshp/research/fundingfor-research-students

Closing Date: 31 January

Funding: Private

Contributor: $£ 1000$ per scholar

Additional Information: If you have any questions about the Bonnart Trust $\mathrm{PhD}$ Scholarhip, please contact: sshpstudentships@bbk.ac.uk www.bbk.ac.uk/student-services/ financial-support/phd-funding/bonnart-trust-scholarship

\section{For further information contact:}

School of Social Sciences, History and Philosophy, Birkbeck, University of London, 26 Russell Square London, United Kingdom.

Email: sshp-studentships@bbk.ac.uk

\section{School of Arts Master's Bursaries and Studentships}

Purpose: We are delighted to be able to offer up to twenty bursaries to Masters students coming into the School of Arts, Birkbeck. Please see details of each available award and application deadlines below. All applications should be made using the right application form which must be completed in addition to a College application.

Eligibility: 1. Level: Postgraduate Taught. 2. Fees: Home, EU or International. 3. Applicants should have an outstanding academic record and show excellent promise.

Type: Bursaries

Value: Up to $£ 20,000$

Frequency: 2 years
Closing Date: 29 May

Additional Information: www.bbk.ac.uk/arts/research/ research-bursaries-studentships-funding/arts-ma-bursaries

\section{Blakemore Foundation}

1201 3rd Avenue, Suite 4900, Seattle, WA 98101-3099, United States of America.

Tel: $\quad$ (1) 2063598778

Email: blakemorefoundation@gmail.com

Website: www.blakemorefoundation.org

Contact: Eugene H. Lee, Trustee

\section{Blakemore Freeman Fellowships for Advanced Asian Language Study}

Purpose: To permit American citizens or permanent residents of the United States to raise their language skills in Chinese, Japanese, Korean, Thai, Vietnamese, Indonesian, Khmer or Burmese to professional working proficiency

Eligibility: Pursuing a professional, business, technical or academic career that involves the regular use of Chinese, Japanese, Korean, Thai, Vietnamese, Indonesian, Khmer or Burmese. 1. By the start of the grant, have (at minimum) a college undergraduate degree. 2. Be at or near an advanced level in the language. By the start of the grant, applicants must have completed (at minimum) the equivalent of the third year of languages classes at the college level, either through classes taken in the United States or through a combination of study at the college level in the United States and intensive language study abroad programs. 3 . Be able to devote oneself exclusively to full-time intensive language study during the term of the grant; grants are not made for part-time study or research. 4 . Be a citizen or permanent resident of the United States of America Type: A variable number of grants

Value: Full tuition at approved language schools in East \& SE Asia plus stipend for travel, study \& living expenses

Length of Study: 9-10 months

Frequency: Annual

Study Establishment: See website for list of approved language programs

Country of Study: Other

Application Procedure: To apply for a Blakemore Freeman Fellowship the applicant must complete an application form on our application portal at blakemorefoundation. communityforce.com

No. of awards offered: 139

Closing Date: 30 December

Funding: Foundation, Trusts 
Contributor: Blakemore Foundation; The Freeman Foundation No. of awards given last year: 14

No. of applicants last year: 139

Additional Information: Email address above is incorrect: The new email for the Foundation is contactus@ blakemore foundation.org einaudi.cornell.edu/opportunity/blakemorefoundation-blakemore-freeman-fellowships-advanced-asianlanguage-study

\section{Bond University}

School of Business, c/o International Office, Gold Coast QLD 4229, Australia.
Tel:
(61) 755951706
Email: international@bond.edu.au
Contact:

\section{Bond University United Kingdom Excellence Scholarship in Australia}

Purpose: Bond University is now accepting applications from citizens of the United Kingdom for the United Kingdom Excellence Scholarship. Bond University aims to help identify future leaders and realize their full potential by providing access to an exceptional educational experience

Eligibility: To be considered applicants must: High achieving citizens of the United Kingdom who are currently residing outside of Australia are encouraged to apply; Applicants must have received an offer to study at Bond prior to applying. People studying in English as part of packaged offers at the Bond University College are still eligible to apply; Keep excellent academic qualifications; Students have already received a proposal from Bond University to start a bachelor or postgraduate degree; Examples of high academic achievement may include students with high achieving A Level or IB results; High achieving academic students applying for the undergraduate study who are not currently completing an Australian High School equivalent in the United Kingdom are also eligible to apply

Level of Study: Postgraduate

Type: Scholarship

Value: $25 \%$ tuition remission

Frequency: Annual

Country of Study: Australia, the United Kingdom, Europe or the United States of America

Application Procedure: To apply, students must complete the Bond University Online Application Form to receive their program offer before applying for this scholarship. 1. Once an offer has been received, students must download and complete the United Kingdom Excellence Scholarship
Application Form through the given link: Application Form. 2. Applicants must submit their complete application to international@bond.edu.au

Closing Date: 21 February

Funding: Private

Contributor: Bond University

Additional Information: Applications close on 24 May for students commencing in September semester bond.edu.au/ intl/scholarship/uk-excellence-scholarship

\section{For further information contact:}

14 University Drive, Robina, QLD 4226, Australia.

\section{Boren Awards}

\section{Boren Scholarship}

Purpose: Boren Scholars represent a vital pool of highly motivated individuals who wish to work in the federal national security arena. In exchange for funding, Boren Scholars commit to working in the federal government for at least one year after graduation

Eligibility: 1. A United States citizen at the time of application. 2. A high school graduate, or have earned a GED. 3. Matriculated in an undergraduate degree program located within the United States accredited by an accrediting body recognized by the United States Department of Education. Boren Scholars must remain matriculated in their undergraduate programs for the duration of the scholarship and may not graduate until the scholarship is complete. 4. Applying to a study abroad program that meets home institution standards in a country outside of Western Europe, Canada, Australia, or New Zealand. Boren Scholarships are not for study in the United States

Level of Study: Graduate

Type: Scholarship

Value: Up to US $\$ 20,000$ for $25-52$ weeks (preferred), US\$10,000 for 12-24 weeks, US\$8,000 for 8-11 weeks (STEM majors only)

Frequency: Annual

Country of Study: United States of America

Closing Date: 1 March

Funding: Private

Additional Information: www.borenawards.org/

\section{For further information contact:}

1400 K Street, NW 7TH floor, Washington DC 20005, United States of America.

Tel: (1) 8006186737

Email: boren@iie.org 


\section{Botswana Insurance Holdings Limited Trust}

PO Box 336, Gaborone, BW, Botswana.

Tel: $\quad$ (267) 3707400

Email: webmaster@bihl.co.bw

Website: www.bihl.co.bw/

BIHL Group is a leading financial services group, originally established in 1975. BIHL has been listed on the Botswana Stock Exchange and is the holding company for three subsidiaries and holds a stake in two associate companies.

\section{Botswana Insurance Holdings Limited Trust Thomas Tlou Scholarship for Master Programme}

Purpose: The BIHL Trust Thomas Tlou Scholarship aims to benefit talented young Batswana with aspirations to pursue postgraduate studies in any discipline aimed at contributing to Botswana's socio-economic development

Eligibility: The scholarship is open to all citizens of Botswana who wish to pursue a master's programme in any discipline at a local reputable and recognized institution of higher learning on Botswana. The intended recipients must be aged between 18-35

Level of Study: Postgraduate

Type: Scholarship

Value: The Trust will spend a total of P 450,000

Country of Study: Any country

Application Procedure: Citizens of Botswana can apply for this scholarship

Closing Date: 30 June

\section{For further information contact:}

BIHL Group, Plot 66458, Block A, 3rd Floor, Fairgrounds

Office Park, Gaborone, Botswana.

Fax: (267) 3973705

Email: tkeepetsoe@bihl.co.bw

\section{Bournemouth University}

Fern Barrow, Poole, Dorset, BH12 5BB, United Kingdom.

Tel:

(44) 1202524111

Email:_enquiries@bournemouth.ac.uk
Website: www.bournemouth.ac.uk

Contact: Ms Karen Ward, Research Administrator

If you choose BU, you'll be learning from top academics in a community of academic excellence, with excellent industry links, accredited courses and placement opportunities, preparing you for professional practice. With a range of scholarships available, there's never been a better time to take charge of your own future with BU.

\section{Bournemouth University Dean}

Eligibility: You will need to have a minimum of an upper second-class honours degree (2i). You cannot be in receipt of any other BU scholarship

Type: Scholarship

Frequency: Annual

Study Establishment: Bournemouth University

Country of Study: Any country

Application Procedure: Apply via online application form available on the BU website

Closing Date: 31 May

Contributor: Bournemouth University

\section{Bournemouth University Dean's Scholarship - The Media School}

Eligibility: You will need to have a minimum of an upper second-class honours degree (2i), or overseas equivalent

Level of Study: Graduate, Postgraduate

Value: $50 \%$ tuition fee reduction

Country of Study: Any country

Closing Date: 31 July

\section{Bournemouth University Music Scholarships}

Purpose: The scholarship supports young people with academic ability, leadership potential and a commitment to their community to achieve their full academic and leadership potential

Eligibility: Any UK, EU or international applicant applying for a full-time undergraduate or postgraduate course at BU

Type: Scholarship

Value: $£ 600$

Frequency: Annual

Study Establishment: Bournemouth University

Country of Study: United Kingdom 
Application Procedure: Apply via online form available on the BU website. As part of your application, you will need to source two references. Referees can include your Director of Music, music teacher, instrumental/vocal coach, ensemble conductor etc, or any other person qualified to write about your musical abilities. They need to complete and submit the online reference form. Scholarships will be awarded for the first year of study and may be continued for subsequent years of study providing you continue to meet the criteria

No. of awards offered: 15

Closing Date: 31 August

Contributor: Bournemouth University

No. of applicants last year: 15

Additional Information: www.bournemouth.ac.uk/study/ undergraduate/fees-funding/scholarships/ukeu-student-scholar ships/bu-music-scholarships

\section{For further information contact:}

Tel: (44) 1202961916

\section{Bournemouth University Vice-Chancellor's Scholarship - Most Promising Postgraduate Applicant}

Eligibility: Any United Kingdom or European Union student who has completed an undergraduate degree at $\mathrm{BU}$ and who is applying for postgraduate study at BU

Level of Study: Graduate, Postgraduate

Country of Study: Any country

\section{Reham al-Farra International Scholarship in Journalism}

Purpose: The Reham Al-Farra Memorial Journalism Fellowship is a unique opportunity for young journalists from developing countries and countries with economies in transition to cover the United Nations

Eligibility: The Reham al-Farra International Scholarship in Journalism is offered to an international applicant for MA Multimedia Journalism. You must be classed as an overseas student for fees purposes. You cannot be in receipt of any other BU scholarships

Type: Scholarship

Value: $£ 3,000$

Frequency: Annual

Study Establishment: Bournemouth University

Country of Study: Any country

Application Procedure: Apply via online form available on the BU website

Closing Date: 31 May
Funding: Private

Contributor: Bournemouth University

Additional Information: www.european-funding-guide.eu/ scholarship/11272-reham-al-farra-international-scholarshipjournalism

\section{The Business School Dean's Scholarship}

Eligibility: You must be an applicant for a full-time taught Master's degree delivered by The Business School. Applicants will be considered based upon: 1 . Academic achievement. 2. Work or voluntary experience relevant to the programme for which they have applied. 3. Any additional skills, experience or extra-curricular activities that will add value and indicate that they will make a significant contribution to the cohort on the programme or the Business School

Level of Study: Graduate, Postgraduate

Type: Scholarship

Value: up to $£ 12,500$

Frequency: Annual

Country of Study: Any country

Application Procedure: In order to apply for the scholarship, the following steps needs to be followed. To secure the scholarship award applicants must confirm acceptance of the award by the date stated on the scholarship offer email. Failure to confirm acceptance of the scholarship by this date may result in the applicant's right to the scholarship being removed and the scholarship being awarded to another applicant

Closing Date: 31 May

Additional Information: www.european-funding-guide.eu/ scholarship/11270-business-school-dean $\%$ E2\%80\%99s-mbascholarship

\section{Bradford Chamber of Commerce and Industry}

Devere House, Vicar Lane, Little Germany, Bradford, Yorkshire BD1 5AH, United Kingdom.

Tel: $\quad$ (44) 1274772777

Email: info@bradfordchamber.co.uk

Website: www.bradfordchamber.co.uk

Contact: Julie Snook, Financial Controller

The Bradford Chamber of Commerce and Industry represents member companies in the Bradford and district area. It works with local partners to develop the economic health of the district and has a major voice within the British Chamber of 
Commerce movement in order to promote the needs of local business on a national basis.

\section{John Speak Trust Scholarships}

Purpose: To promote British trade abroad by assisting people in perfecting their basic knowledge of a foreign language

Eligibility: Open to British nationals intending to follow a career connected with the export trade in the United Kingdom. Applicants must be over 18 years of age with a sound, basic knowledge of at least one language

Level of Study: Professional development

Type: Scholarship

Value: 1. A financial Award ranging from $£ 500$ up to $£ 2,000$ towards living expenses. 2. Possible assistance with travel costs (up to $£ 500$ ) - individually assessed. 3. An opportunity to improve language skills and learn new customs. 4. Experience living abroad whilst studying a foreign language. 5. Gain valuable experience to assist in a chosen career. 6.n individually assessed application by the John Speak Committee

Length of Study: Between 3 months and 1 full academic year abroad depending on the circumstances and each candidate

Frequency: Annual

Study Establishment: A recognized college or university Country of Study: Any country

Application Procedure: Applicants must complete an application form and undertake an interview

No. of awards offered: 14

Closing Date: 24 April

Funding: Private

No. of awards given last year: 10

No. of applicants last year: 14

Additional Information: www.johnspeaktrust.co.uk/newapplications-for-scholarships-are-invited-from-1st-sept-2017/

\section{Brain Research Institute}

Florey Institute of Neuroscience and Mental Health, Melbourne Brain Centre - Austin campus, 245 Burgundy Street, Heidelberg, VIC 3084, Australia.

Tel: $\quad$ (61) 390357000

Email:_BRI@brain.org.au

Website: www.brain.org.au/

The Brain Research Institute (BRI) was established at Austin Health, Melbourne, Australia in 1996. It supports collaboration between specialities in order to develop a better understanding of how a healthy or diseased brain functions. It is an affiliated institution of The University of Melbourne

\section{Brain Research Institute PhD Scholarships}

Purpose: To encourage competitive research in understanding the structure and function of the human brain

Eligibility: Open to candidates who have obtained Honours 1 or equivalent, or Honours $2 \mathrm{a}$ or equivalent

Level of Study: Doctorate

Type: Scholarship

Value: Varies

Length of Study: 3 years

Frequency: Annual

Country of Study: Australia

Application Procedure: Applicants must send a curriculum vitae, academic transcripts, expression of interest for area of research and details of two academic referees

\section{For further information contact:}

Email: scholarships@brain.org.au

\section{BrightFocus Foundation}

22512 Gateway Center Drive, Clarksburg, MD 20871, United States of America.

Tel: $\quad$ (1) 8004372423

Email: info@brightfocus.org

Website: www.brightfocus.org/

Contact: Dr Kara Summers, Grants Coordinator

BrightFocus Foundation (formerly American Health Assistance Foundation [AHAF]) is a non-profit charitable organization that funds research and public education on age related and degenerative diseases including: Alzheimer's disease, macular degeneration, glaucoma.

\section{American Health Assistance Foundation Macular Degeneration Research}

Purpose: To enable basic research on the causes of, or the treatment for, macular degeneration

Eligibility: The principal investigator must hold a tenure track or tenured position and the rank of assistant professor or higher

Level of Study: Research 
Type: Grant

Value: maximum US $\$ 60,000$ per year, payable over 2 years (total value US\$120,000)

Length of Study: 2 year

Frequency: Annual

Study Establishment: Non-profit institutions and organizations

Country of Study: Any country

Application Procedure: Applicants must complete an application form. The current application form should be requested for each year or can be downloaded from the website

No. of awards offered: 81

Closing Date: July

Funding: Private

No. of awards given last year: 16

No. of applicants last year: 81

Additional Information: www.brightfocus.org/grants/ request-proposal-fy20-macular-degeneration-research-program

\section{For further information contact:}

Email: researchgrants@brightfocus.org

\section{British \& Foreign School Society}

Maybrook House, Godstone Road, Caterham, Surrey, CR3 6RE, United Kingdom.

Tel: (44) 1883331177

Website: www.bfss.org.uk

Contact: Mr J Kidd ACIB, Director

\section{Global Professorships}

Purpose: This programme aims to demonstrate and further enhance the UK's commitment to international research partnerships and collaboration as well as strengthen the UK's research capacity and capability in the humanities and the social sciences.

Eligibility: Applications must be submitted online using the British Academy's grants application system, Flexi-Grant. Be a world-class internationally-recognised mid-career to senior researchers who are currently employed outside the United Kingdom, on a permanent contract (which may be part-time or full-time) or, if temporary, would normally be on a contract that will not end during the course of the grant unless expressly agreed with the Academy prior to the application being submitted that such an application would be considered eligible, in any field of the humanities or the social sciences. Hold a doctoral degree (or have equivalent research experience). Be available to take up an unpaid leave of absence, a long-term secondment or employment at an eligible United Kingdom host institution. Eligible institutions include but are not limited to the British International Research Institutes

Level of Study: Graduate, Postgraduate, Professional development, Research, Unrestricted

Type: Position (Employment)

Value: up to $£ 187,500$ per annum, and up to $£ 750,000$ over four years

Length of Study: For a period of 4 years

Frequency: Every 3 years

Country of Study: United Kingdom

Application Procedure: 1. Applications must be submitted online using the British Academy's grants application system, Flexi-Grant. 2.Application, reference, supporting statement and UK host institution application approval deadline: 17.00 (UK time) on Wednesday 19 February 2020.

Closing Date: 19 February

Funding: Government

Additional Information: All eligible proposals submitted in response to this funding call will be assessed by relevant British Academy peer reviewers and then considered by a final selection panel www.ucl.ac.uk/history/news/2019/oct/ british-academy-funding-call-global-professorships-2020

\section{For further information contact:}

Tel: (44) 2079695220

Email: internationalgrants@thebritishacademy.ac.uk

\section{The British \& Foreign School Society}

Purpose: We support charitable organisations that work to improve access to education or the quality of education for children and young people in remote or impoverished areas both in the UK and internationally. We do not have a particular geographic preference or focus.

Eligibility: 1. Organisations applying for funding should have UK charitable status or, in the case of schools, colleges, universities and Churches, "exempt charity" status. We do not fund non-UK based organisations, Community Interest Companies (CICs) or individuals. 2. Organisations should have continuous UK accounts for at least three years. 3. BFSS will only fund one project per charity at a time. If you are running a project with our funding, you cannot apply for a new grant until you have submitted your final project report. 4. BFSS focuses support on small to medium sized organisations who do not have ready access to much larger funding sources. We therefore do not usually fund charities with an average annual income above $£ 2.5$ million or below $£ 5,000$, except in exceptional circumstances. These restrictions do not apply to UK 
based schools, colleges and other educational establishments. 5. Organisations should be directly involved in the provision of charitable services. We do not fund organisations whose primary purpose is fundraising. 6. We encourage close partnerships with local organisations. However, the applicant organisation must be willing to take full responsibility for the management, delivery, finances and integrity of the project.

Application Procedure: Applications from charitable organisations which meet the grant criteria are initially reviewed by the BFSS Grants Manager, and may then be submitted to the Grants Committee, which normally meets three times a year.

Additional Information: bfss.org.uk/grants/

For further information contact:

7-14 Great Dover St, London, SE1 4YR, United Kingdom.

Tel: (44) 2079227814

Email: grants@bfss.org.uk

\section{British Academy}

10-11 Carlton House Terrace, London, SW1Y 5AH, United Kingdom.

Tel: $\quad$ (44) 2079695200

Email: chiefexec@britac.ac.uk

Website: www.britac.ac.uk

Contact: Dr Ken Emond, Head of Research Awards

The British Academy is the premier national learned society in the United Kingdom devoted to the promotion of advanced research and scholarship in the humanities and social sciences.

\section{Browning Fund Grants}

Purpose: To promote historical studies in the field of British history in the early modern period with particular reference to the 17 th century

Eligibility: Applicants must be of postdoctoral status and ordinarily resident in the United Kingdom

Level of Study: Postdoctorate

Type: Research grant

Value: Up to $£ 10,000$

Length of Study: Up to 2 years
Frequency: Annual

Country of Study: Any country

Application Procedure: Application must be made to the

BA/Leverhulme Small Research Grants Scheme via the

BA's online e-GAP system at egap.britac.ac.uk

No. of awards offered: Part of a larger scheme

Funding: Private

No. of awards given last year: 1

No. of applicants last year: Part of a larger scheme

Additional Information: www.britac.ac.uk

\section{For further information contact:}

Email: bfi@brownfoundation.org

\section{Early Childhood Development Funding}

Purpose: This programme is intended as the foundation for a wider research programme in subsequent years and thus aims to support a new generation of interlinked research and policy intervention that focuses on what works at scale in different contexts whilst building, and working with, local capacity to deliver effective research and change

Eligibility: 1. The Early Childhood Development Programme is open to researchers based at United Kingdom and overseas institutions. The main applicant must be based at a university or research institute and be of postdoctoral or above equivalent status. 2. The applicant must either be in a permanent position at the institution or have a fixed-term position for the duration of the award

Level of Study: Graduate

Type: Funding support

Frequency: Varies

Country of Study: Any country

Closing Date: 21 June

Funding: Private

\section{For further information contact:}

10-11 Carlton House Terrace, London, SW1Y 5AH, United Kingdom.

Email: ECD@britac.ac.uk

\section{Honor Frost Foundation Grants}

Purpose: To provide support for research maritime archaeology and maritime cultural heritage

Level of Study: Postdoctorate

Type: Research grant

Value: Up to $£ 10,000$ 
Length of Study: Up to 2 years

Frequency: Annual

Application Procedure: Applications must be submitted via e-GAP2, the Academy's electronic grant application system, by applying for a BA/Leverhulme Small Research Grant

No. of awards offered: Part of a larger scheme

Funding: Private

Contributor: Honor Frost Foundation

No. of awards given last year: 2

No. of applicants last year: Part of a larger scheme

Additional Information: www.thebritishacademy.ac.uk/ funding/honor-frost-foundation

\section{For further information contact:}

Email: rebeccagould@honorfrostfoundation.org

\section{Newton International Fellowships}

Purpose: The Newton International Fellowships aim to attract the most promising early career postdoctoral researchers from overseas in the fields of natural sciences, physical sciences, medical sciences, social sciences and the humanities. The Newton International Fellowships enable researchers to work for two years at a UK institution with the aim of fostering long-term international collaborations.

Eligibility: Applicants must have a $\mathrm{PhD}$, have no more than 7 years of active full time postdoctoral experience, be working outside the UK, and not hold UK citizenship.

Level of Study: Postdoctorate

Length of Study: Up to 2 years

Closing Date: 8 April

Additional Information: www.thebritishacademy.ac.uk/ funding/funding-opportunities

\section{Newton Mobility Grants}

Purpose: Newton Mobility Grants provide support for international researchers based in a country covered by the Newton Fund to establish and develop collaboration with UK researchers around a specific jointly defined research project. Eligibility: Both a UK-based applicant and an overseas-based applicant are required for this scheme. Both applicants must have a $\mathrm{PhD}$ or equivalent research experience and hold a permanent or fixed-term contract in an eligible university or research institute, which must span the duration of the project. Collaborations should focus on a single jointly defined research project involving (or lead by) the two applicants.

Level of Study: Research
Type: Grant

Value: maximum of $£ 10,000$

Length of Study: 1 year

Frequency: Annual

Country of Study: United Kingdom

Application Procedure: Applications must be submitted online using the British Academy's online grants management system, Flexi-Grant. For the assessment criteria please see the detailed scheme notes.

Closing Date: 5 September

Funding: Private

Contributor: Newton Fund

Additional Information: www.thebritishacademy.ac.uk/ funding/newton-mobility-grants

\section{For further information contact:}

10-11 Carlton House Terrace, London, SW1Y 5AH, United Kingdom.

Tel:

(44) 2079695217

Email: newtonfund@thebritishacademy.ac.uk

\section{Sir Ernest Cassel Educational Trust Grants}

Purpose: To enable early career researchers to travel overseas as part of a winter project supported under the BA/Leverhulme Small Research Grants Scheme

Eligibility: Applicants must be of postdoctoral status and ordinarily resident in the United Kingdom, and must be early career (within 5 years of the award or the doctorate)

Level of Study: Postdoctorate

Type: Research grant

Value: Normally not more than $£ 1,000$

Length of Study: Up to 2 years

Frequency: Annual

Country of Study: Any country

Application Procedure: Application must be made to the BA/Leverhulme small research Grants online e-GAP system at egap.britac.ac.uk

No. of awards offered: Part of a larger scheme

Closing Date: July

Funding: Private

Contributor: Sir Ernest Cassel Trust

No. of awards given last year: 11

No. of applicants last year: Part of a larger scheme

Additional Information: www.casseltrust.co.uk/

\section{For further information contact:}

Email: casseltrust@btinternet.com 


\section{British Association for American Studies (BAAS)}

American Studies, School of Humanities, Keele University, Staffordshire, ST5 5BG, United Kingdom.

\author{
Tel: (44) 1782732000 \\ Email:_jo.gill@baas.ac.uk \\ Website: www.baas.ac.uk \\ Contact: Dr Sue Currell, BAAS Chair
}

The British Association for American Studies (BAAS), established in 1955, promotes research and teaching in all aspects of American studies. The Association organizes annual conferences and specialist regional meetings for students, teachers and researchers. The publications produced are The Journal of American Studies with Cambridge University Press, BAAS Paperbacks with Edinburgh University Press and British Records Relating to America in Microform with Microform Publishing.

\section{British Association for American Studies Postgraduate and Early Career Short-Term Travel Awards}

Purpose: To foster talent among the American Studies community in the United Kingdom. Fund travel to the United States of America for short-term research projects

Eligibility: Open to residents in the United Kingdom. Preference is given to young postgraduates and to members of BAAS. Successful candidates are required to provide a brief report of their research trip for publication in American Studies in Britain, and they are requested to acknowledge the assistance of BAAS in any other publication that results from research carried out during the tenure of the award Level of Study: Doctorate, Postdoctorate, Postgraduate, Professional development

Type: Award

Value: $£ 1,000$

Frequency: Annual

Country of Study: United Kingdom or Australia

Application Procedure: Applicants must complete an application form

No. of awards offered: Classified

Closing Date: 10 December

Funding: Foundation

Contributor: American Embassy

No. of awards given last year: 6
No. of applicants last year: Classified

Additional Information: Successful candidates must write a report and acknowledge BAAS assistance in any related publication. Please contact at awards@baas.ac.uk www.baas. ac.uk/baas-postgraduate-short-term-travel-awards-2009/

\section{For further information contact:}

Email: awards@baas.ac.uk

\section{British Association for Canadian Studies (BACS)}

UCL Institute of the Americas 51 Gordon Square, London, WC1H 0PN, United Kingdom.

Tel: $\quad$ (44) 2031089711

Email: bacs@canadian-studies.org

Website: www.canadian-studies.net

Contact: Dr Tony McCulloch, President

In response to the growing academic interest in Canada, the British Association for Canadian Studies (BACS) was established in 1975. Its aim is to foster teaching and research on Canada and Canadian issues by locating study resources in Britain, facilitating travel and exchange schemes for professorial staff and ensuring that the expertise of Canadian scholars who visit the United Kingdom is put to effective use. Principal activities include the publication of The British Journal of Canadian Studies and the BACS Newsletter, and the organization of the Association's annual multidisciplinary conference, which attracts scholars from Canada and Europe as well as from the United Kingdom.

\section{Ontario Bicentennial Award}

Purpose: To fund travel to Ontario to research topics concerned with that province in history or political science

Eligibility: Graduate students will normally only be considered in the final stages of their doctoral research, priority will be given to BACS members

Level of Study: Doctorate

Type: Travel grant

Value: C\$500 approximately

Length of Study: Short visit

Frequency: Dependent on funds available

Study Establishment: University or library 
Country of Study: Canada

Application Procedure: Application form, plus supporting letter, curriculum vitae, and the names of two referees must be submitted

No. of awards offered: 2

Closing Date: 1 May

No. of awards given last year: 1

No. of applicants last year: 2

Additional Information: Administered by BACS on behalf of the Foundation for Canadian Studies in the United Kingdom

\section{British Association for Japanese Studies}

c/o Mrs Lynn Baird, BAJS Secretariat, University of Essex, Wivenhoe Park, Colchester, Essex, CO4 3SQ, United Kingdom.

Tel: $\quad$ (44) 7580178960

Email:_bajs@bajs.org.uk

Website: www.bajs.org.uk

The Association was formed in 1974, with the 'aim to encourage Japanese studies in the United Kingdom, in particular by stimulating teaching and research'. With this in mind, the Association's first Conference was convened in Cambridge at Easter 1975, and since then the BAJS Conference has been an annual event.

\section{British Association for Japanese Studies Postgraduate Studentships}

Eligibility: The studentships are open to postgraduate or prospective postgraduate students of all nationalities. Applicants must have been accepted onto a full-time or part-time course at a United Kingdom university at the time application. Their dissertation (or proposed dissertation) must be in the field of Japanese studies. For PhD students in particular, it will normally be expected that they will be using Japanese language materials in their research. They must use the award either to contribute towards their fees, maintenance, or extended fieldwork. Applicants must be a member of BAJS at the time of application

Type: Studentship

Value: Up to 5 individual scholarships of $£ 4,000$ will be granted for use in given academic year. No awards of less than $£ 4,000$ will be made

Country of Study: United Kingdom
Application Procedure: Application for BAJS Postgraduate Studentships is via the online application form. For detailed information, please visit www.bajs.org.uk/funding/bajs studentship/

Closing Date: 15 May

Additional Information: Applicants will not be eligible to receive an award if they accept full scholarships from the AHRC, ESRC, or any other funding body (United Kingdom or overseas). Successful applicants will be expected to acknowledge the support of BAJS in their dissertations, presentations, and any subsequent publications; they will also be expected to submit a 500-word report on how they used the studentship to BAJS council by the end of November. Unsuccessful applicants will be considered for the BAJS Toshiba International Foundation studentship, provided they are eligible worldscholarshipforum.com/bajs-postgraduate-studentshipsinternational-students-uk-2017/

For further information contact:

Email: h.spurling@southampton.ac.uk

\section{British Association of Plastic Reconstructive and Aesthetic Surgeons (BAPRAS)}

The Royal College of Surgeons, 35-43 Lincoln's Inn Fields, London, WC2A 3PE, United Kingdom.

Tel: $\quad$ (44) 2078315161

Email: secretariat@bapras.org.uk

Website: www.bapras.org.uk

Contact: Ms Angela Rausch, Administrator

Founded in 1946 as British Association of Plastic Surgeons. The objective of the association is to relieve sickness and to protect and preserve public health by the promotion and development of Plastic Surgery. A name change to British Association of Plastic Reconstructive and Aesthetic Surgeons (BAPRAS).

\section{British Association of Plastic Reconstructive and Aesthetic Surgeons European Travelling Scholarships}

Purpose: To enable Specialist Registrars from United Kingdom to visit any plastic surgical centre in Europe 
Eligibility: Specialist Registrars (4-6) enrolled on a recognised training programme with the Specialist Advisory Committee in plastic surgery are eligible to apply. Preference will be given to trainees travelling abroad without other financial awards and those applying for funding prior travel. Candidates seeking funds to travel abroad in paid jobs are less preferred

Type: Scholarship

Value: Maximum value of one award is $£ 5,000$

Frequency: Annual

Study Establishment: Plastic Surgery Units

Country of Study: European Union

Application Procedure: Applicants should complete an application form, submit a proposed itinerary that should be detailed and give costs and the reasons for particular visits and a curriculum vitae (maximum length of two pages) to the Chairman of the Education and Research Sub-Committee, BAPRAS

No. of awards offered: 1

Closing Date: 10 December

No. of awards given last year: 1

No. of applicants last year: 1

For further information contact:

Email: bursaries@bapras.org.uk

Travelling Bursaries for Presentation at Overseas Meetings

Purpose: To cover the expenses for overseas travel by a consultant or trainee to present papers at international meetings

Eligibility: Applicants must submit an application form to the Chairman of the Education and Research Sub-Committee, BAPRAS

Type: Travel award

Value: $£ 600$

Frequency: Annual

Study Establishment: Various

Country of Study: Any country

Application Procedure: Applicants must submit application form, abstract of paper to be presented and letter of acceptance to BAPRAS secretariat

No. of awards offered: 9

Closing Date: 10 December

Contributor: BAPRAS

No. of awards given last year: 5

No. of applicants last year: 9

Additional Information: www.bapras.org.uk/professionals/ training-and-education/prizes-grants-and-fellowships/travellingbursaries-for-presentations-overseas

\section{For further information contact:}

Email: bursaries@bapras.org.uk

\section{British Broadcasting Corporation Writersroom}

1st Floor, Grafton House, 379-381 Euston Road, London, NW1 3AU, United Kingdom.

Email: writersroom@bbc.co.uk

Website: www.bbc.co.uk/writersroom/opportunity

BBC Writersroom identifies and champions new writing talent and diversity across BBC Drama, Entertainment and Children's programmes. Writersroom is constantly on the lookout for writers of any age and experience who show real potential for the BBC. It invests in new writing projects nationwide and builds creative partnerships, including work with theatres, writer's organizations and film agencies across the country.

\section{Alfred Bradley Bursary Award}

Purpose: The aim of the Award is to encourage new radio drama writing in the North of United Kingdom

Eligibility: Open to people who live in the North of United Kingdom and who have not had a previous network radio drama commission

Level of Study: Professional development

Type: Bursary

Value: Up to $£ 5,000$, writing bursary and the chance of a Radio 4 drama commission to Northern writers new to radio, and a 12 month mentorship with a Radio Drama producer

Frequency: Every 2 years

Country of Study: United Kingdom

Application Procedure: Applicants must send completed afternoon play scripts for consideration. Details published on www.bbc.co.uk/writersroom

Closing Date: 9 November

Funding: Private, Corporation

Contributor: $\mathrm{BBC}$

Additional Information: There is a change of focus for each award, e.g. previous years have targeted comedy, drama, verse drama, etc.

\section{For further information contact:}

Email: admin@nawe.co.uk 


\section{British Council}

Bridgewater House, 58 Whitworth Street, M1 6BB, Manchester, M1 6BB, United Kingdom.

Tel: (44) 1619577755

Email: general.enquiries@britishcouncil.org

Website: www.britishcouncil.org

The British Council is the United Kingdom's public diplomacy and cultural organization working in more than 100 countries, in arts, education, governance and science. The British Council promotes the diversity and creativity of British society and culture. The Foreign and Commonwealth Office provides The British Council with the core grant-inaid.

\section{Commonwealth Scholarships}

Purpose: For students from the developed Commonwealth to study in the United Kingdom

Eligibility: Please check at

Level of Study: Doctorate

Type: Scholarship

Value: Student visas for the United Kingdom will be arranged gratis by the British Council

Application Procedure: See British Council website

Closing Date: 22 February

Funding: Government

\section{For further information contact:}

Department of Higher Education, External Scholarship Division, ES.4 Section, West Block-1, Wing-6, 2nd Floor, R.K. Puram, New Delhi 110066, India.

Tel: $\quad$ (91) $1126172491 / 26172492$

Email: delhi.scholarship@in.britishcouncil.org

\section{Marshall Scholarships}

Purpose: To finance young Americans of high ability to study for a degree in the United Kingdom

Eligibility: 1. Be citizens of the United States of America (at the time they apply for a scholarship); 2. (By the time they take up their scholarship ie September 2021) hold their first undergraduate degree from an accredited four-year college or university in the United States; 3. Have obtained a grade point average of not less than 3.7 on their undergraduate degree. (Applicants must have a GPA of 3.7 at the time of application). We do not accept rounded GPA's. 4. Have graduated from their first undergraduate college or university after April 2018. 5. Not have studied for, or hold a degree or degreeequivalent qualification from a British University or GCSE or A Levels taken at school in the UK.

Type: Scholarship

Value: University fees, cost of living expenses, annual book grant, thesis grant, research and daily travel grants, fares to and from the United States and, where applicable, a contribution towards the support of a dependent spouse

Frequency: Annual

Country of Study: United Kingdom

Closing Date: October

Funding: Government

Contributor: British Council

No. of awards given last year: 40

Additional Information: www.marshallscholarship.org/ apply/criteria-and-who-is-eligible

\section{For further information contact:}

11766 Wilshire Boulevard, Suite 1200, Los Angeles, CA 90025-6538, United States of America.

Tel: $\quad$ (1) 3109963028

Email:_Losangeles@marshallscholarship.org

\section{The Goa Education Trust (GET) Scholarships}

Purpose: To provide opportunities for dynamic young men and women of Goan origin who have demonstrated academic excellence and extra-curricular achievements to study or train in the United Kingdom

Eligibility: Open to Indian nationals, domiciled and resident in Goa or born of Goan parents, who are not more than 30 years of age at the time of applying for the scholarship and have an excellent academic track record. Candidates must have confirmed admission for any technical/vocational/academic course of study in the United Kingdom for up to 1 year Level of Study: Postgraduate

Type: Scholarship

Value: Scholarships will fund young Indians to pursue a Masters in the United Kingdom and will cover part or full tuition fees not exceeding $£ 15,000$

Length of Study: 1 year

Frequency: Annual

Country of Study: United Kingdom

Application Procedure: A completed application form must be sent by post 
Closing Date: 10 May

Additional Information: studyabroad.shiksha.com/scholar ships/goa-education-trust-scholarships

\section{For further information contact:}

British Council Division, British Deputy High Commission, 901, 9th Floor, Tower1, One Indiabulls Centre, 841, Senapati Bapat Marg, Elphinstone Road (West), Mumbai 400 013, India.

Tel: $\quad$ (91) 2267486748

Email: mumbai.enquiry@in.britishcouncil.org

\section{British Dental Association}

64 Wimpole Street, London, W1G 8YS, United Kingdom.

Tel: $\quad$ (44) 2079350875

Email:_enquiries@bda.org

Website: www.bda.org

Contact: Miss Sarah Leithead, Marketing Executive

The British Dental Association (BDA) is the national professional association for dentists. With over 20,000 members, the Association strives to enhance the science, art and ethics of dentistry, improve the nation's oral health and promote the interests of its members.

\section{British Dental Association/Dentsply Student Support Fund}

Purpose: To give financial assistance to students who are in severe financial hardship. Only open to 4th- and 5th-year BDS students or postgraduates

Eligibility: Open to BDA members only. All applicants must be registered students at a United Kingdom Dental School

Level of Study: Graduate, Postgraduate

Type: Scholarship/Hardship fund

Value: Varies

Frequency: Annual

Country of Study: United Kingdom

Application Procedure: Applicants must complete and submit application forms, accompanied by an academic reference or supporting letter. Application forms can be found in the student section of the BDA website

No. of awards offered: 30

Closing Date: 1 July

Funding: Commercial
Contributor: Dentsply United Kingdom Ltd

No. of awards given last year: 7

No. of applicants last year: 30

Additional Information: For BDS/Dental Students only

For further information contact:

Email: SSF@contacts.bham.ac.uk

\section{British Dietetic Association}

The British Dietetic Association, 5th floor, Charles House, 148/9 Great Charles Street Queensway, Birmingham, B3 3HT, United Kingdom.

Tel:

$$
\text { (44) } 121200802
$$

Email: info@bda.uk.com

Website: www.bda.uk.com

Contact: Mr Nula Marnell, Assistant to the Chief

Executive

The British Dietetic Association (BDA) is the professional body for dietitians in the United Kingdom and provides grants for research into human nutrition and dietetic practice that advances the profession.

\section{Pace Award}

Purpose: For the development or implementation of a nutrition education programme for staff addressing the problem of undernutrition

Eligibility: Applicants should be full members of the BDA and resident in the United Kingdom or Eire

Level of Study: Research

Type: Grant

Value: $£ 500$ to fund the development of the project and $£ 300$ worth of pace learning units for staff to use

Country of Study: Any country

Application Procedure: To apply, dietitians are to submit an outline of the proposed education programme that includes: which staff is targeted, subject area and level of the programme, which format will be taken, how the learner will be assessed, what effect it will have on nutritional care and how it will raise the profile of nutrition in your organization, potential benefits to employers and estimated cost of development and implementation. Four copies of the application are to be submitted

Closing Date: 28 January

Funding: Commercial 
Additional Information: Applications should not exceed 1,000 words

\section{For further information contact:}

Email: financial.aid@ohio.edu

\section{British Ecological Society (BES)}

Charles Darwin House, 12 Roger Street, London, Wc1N 2JU, United Kingdom.

Tel:

(44) 2076852500

Email:_grants@britishecologicalsociety.org

Website: www.britishecologicalsociety.org

As a learned society and registered charity, the British Ecological Society (BES) is an independent organization receiving little outside funding. The aims of the Society are to promote the science of ecology through research, publications and conferences and to use the findings of such research to educate the public and to influence policy decisions that involve ecological matters. The BES is an active and thriving organization with something to offer anyone with an interest in ecology. Academic journals, teaching resources, meetings for scientists and policy makers, career advice and grants for ecologists are just a few of the societies areas of activity.

\section{Outreach Grant}

Purpose: To promote ecological science to a wide audience Eligibility: Awards are open to individuals and organizations to organize public engagement events in ecology. This includes, but is not limited to, members of the BES, researchers, schools, museums, libraries and community groups. Applications will not be considered for: staff salaries; Purchase of apparatus, including computers, cameras etc., unless these are integral to the application. Applications from museums and schools are welcome but projects must involve significant outreach beyond schools. Projects aimed solely at delivering curriculum to school children will not be considered Type: Project grant

Value: $£ 2,000$

Frequency: Annual

Country of Study: Any country

Application Procedure: Applicants must complete an online application form through the BES website at www.britisheco logicalsociety.org/grants-awards/outreach-grants

No. of awards offered: 113
Closing Date: 20 March

Contributor: British Ecological Society

No. of awards given last year: 11

No. of applicants last year: 113

Additional Information: Published papers and reports to other organizations should include an acknowledgement of the support from the BES. Other conditions may apply www. britishecologicalsociety.org/funding/outreach-grants/

\section{For further information contact:}

Email: outreach@physoc.org

\section{Training \& Travel Grants}

Purpose: These grants help $\mathrm{PhD}$ students and postgraduate research assistants to meet the costs of specialist field training courses and to network and publicise their research by presenting their work at workshops and conferences.

Eligibility: 1. be a BES member. 2. have at least a B.Sc. or equivalent degree. 3 . be a $\mathrm{PhD}$ student, postgraduate research assistant (within 3 years of completing relevant degree) or equivalent (Postdoc researchers are therefore not eligible to apply).4. work or study at a university or research institution (including field centres, NGOs, museums, etc.) that provide research facilities. 5. work in scientific areas within our remit (the science of ecology) and of relevance to the training course or meeting they are applying to attend. 6 . give a presentation if attending a meeting. 7. no retrospective claims for funding will be considered. 8. no applicant may receive more than two Training \& Travel Grants in any five year period. There must be at least three years between grants.

Type: Grants

Value: $£ 1,000$

Closing Date: September

Additional Information: www.britishecologicalsociety.org/ funding/training-travel-grants/

\section{British Federation of Women Graduates (BFWG)}

4 Mandeville Courtyard, 142 Battersea Park Road, London, SW11 4NB, United Kingdom.

Tel: (44) 2074988037

Email: awards@bfwg.org.uk

Website: www.bfwg.org.uk

The British Federation of Women Graduates (BFWG) provides opportunities to women in education and public life. 
BFWG works as part of an international organization to improve the lives of women and girls, fosters local, national and international friendship and offers scholarships for third year doctorate research.

\section{American Association of University Women/ International Federation of University Women International Fellowships}

Purpose: To assist study or research that demonstrates a continued interest in the advancement of women

Eligibility: Open to female members of the British Federation of Women Graduates (BFWG) or another national federation or association (NFA) of the International Federation of University Women (IFUW), who are not United States citizens, with acceptance by an institution in America at which the applicant proposes to undertake her work

Level of Study: Graduate, Postdoctorate, Postgraduate, Predoctorate, Research

Type: Fellowships

Value: Master's/first professional degree: US\$18,000; Doctoral: US\$20,000; Postdoctoral: US\$30,000. These fellowships do not cover travel costs

Length of Study: 1 year

Frequency: Annual

Study Establishment: An Institute of Higher Education

Country of Study: United States of America

Application Procedure: Application material can be downloaded from AAUW's website

Closing Date: 1 December

Funding: Private

Contributor: AAUW members

Additional Information: A list of NFA's can be found on IFUW's website (www.ifuw.org www.scholars4dev.com/ 1877/aauw-international-fellowships-in-usa-for-women/)

\section{For further information contact:}

AAUW Educational Foundation, International Fellowships, PO Box 4030, Iowa City, IA 52243-4030, United States of America.

Email: aauw@act.org

\section{British Federation of Women Graduates Scholarships}

Purpose: To assist final-year $\mathrm{PhD}$ research students Eligibility: Academic excellence as evidenced by a proven ability to carry out independent research is the chief criterion. Open to female students, regardless of nationality, whose studies take place in Great Britain. Research students should be entering into their final year of formal study towards a PhD degree. Taught Master's degrees do not count as research, although MPhil research students would need to be upgraded to a PhD during the close of the competition or thereabouts

Level of Study: Doctorate, Predoctorate, Research

Type: Scholarship

Value: The amounts offered in awards range upwards from GB£1,000 with the average award being around GB£3,000 and the maximum being $\mathrm{GB} £ 6,000$

Length of Study: Student must be in her third year (or part time equivalent) at the time of giving out the awards (October each year)

Frequency: Annual

Study Establishment: A university or institution of university status in Britain

Country of Study: Great Britain

Application Procedure: Application materials can be downloaded from BFWG's website or www.bfwg.org.uk

No. of awards offered: 235

Closing Date: 18 March

Funding: Private

Contributor: BFWG members

No. of awards given last year: 7

No. of applicants last year: 235

Additional Information: Recipients must submit a written report within 6 months of being awarded their PhD

\section{French Association of University Women (AFFDU) Grants}

Purpose: To assist those at doctoral or postdoctoral levels whose studies or research take place in France

Eligibility: Open to female members of the British Federation of Women Graduates (BFWG) or another national federation or association (NFA) of the International Federation of University Women (IFUW), who know the language of the country in which they plan to study

Level of Study: Doctorate, Postdoctorate, Postgraduate, Research

Type: Grant

Value: $€ 1,000-1,500$, should preferably cover a study or research project involving travelling to or outside of France

Length of Study: Up to 12 months

Frequency: Annual

Study Establishment: An Institute of Higher Education

Country of Study: France

Application Procedure: Applicants should be undergraduate or postgraduate students, should have applied for admission to the University for a full-time scheme and have satisfied the entry requirements

Closing Date: 30 April

Funding: Private 
Contributor: AFFDU members

Additional Information: A list of NFA's can be found on IFUW's website (www.ifuw.org www.european-fundingguide.eu/scholarship/6992-affdu-grants-archaelogy-historyliterature-physics-chemistry)

\section{For further information contact:}

AFFDU, Reid Hall, 4 rue de Chevreuse, F-75006 Paris, France.

Email: affdu@club-internet.fr

\section{French Association of University Women (AFFDU) Monique Fouet Grant}

Purpose: To support a women postgraduate studying Political Science

Eligibility: Open to female members of the British Federation of Women Graduates (BFWG) or another National Federation of Association (NFA) of the International Federation of University Women (IFUW), who wish to undertake research on the AFFDU project site in Nabasdju Civol. Candidates must speak French

Level of Study: Postgraduate, Research

Type: Grant

Value: From $€ 1,000-1,500$. The award does not cover travel costs

Length of Study: Up to 1 year

Frequency: Annual

Study Establishment: A university or institution of university status

Country of Study: Any country

Application Procedure: Application materials can be downloaded from AFFDU's website or obtained via email

Closing Date: March

Funding: Private

Contributor: AFFDU members

Additional Information: A list of NFA's can be found on

IFUW's website (www.ifuw.org)

For further information contact:

AFFDU, Reid Hall, 4 rue de Chevreuse, F-75006 Paris, France.

Email: affdu@club-internet.fr

\section{NKA Ellen Gleditsch Scholarship}

Purpose: To assist independent research or advanced studies by women at the post-graduate or doctoral level
Eligibility: Open to female members of the British Federation of Women Graduates (BFWG) or another national federation or association (NFA) of the International Federation of University Women (IFUW) with acceptance by a Norwegian institution at which the applicant proposes to undertake her work and proof of adequate health insurance

Level of Study: Doctorate, Postgraduate, Research

Type: Scholarship

Value: NOK 40,000. The scholarship does not cover travel costs

Length of Study: 3-4 months

Frequency: Every 3 years

Study Establishment: A university or institution of university status

Country of Study: Norway

Application Procedure: Applicants studying in Great Britain must apply through BFWG. Application material and membership details can be downloaded from their website or for paper copies write to BFWG, 4 Mandeville Courtyard, 142 Battersea Park Road, London SW11 4NB, United Kingdom enclosing a C5 self-addressed stamped envelope

Closing Date: 1 September

Funding: Private

Contributor: NKA members

Additional Information: If studying outside Great Britain, candidates should check the list of NFAs on IFUW's website (www.ifuw.org)

For further information contact:

EGS, PO Box 251, N-5000 Bergen, Norway.

Email: elisabeth.haavet@hi.uib.no

\section{British Heart Foundation (BHF)}

14 Fitzhardinge Street, London, W1H 6DH, United Kingdom.

Tel:

$$
\text { (44) } 2079350185
$$

Email:_internet@bhf.org.uk

Website: www.bhf.org.uk

Contact: Ms Valerie Mason, Research Funds Manager

The British Heart Foundation (BHF) exists to encourage research into the causes, diagnosis, prevention and advances of cardiovascular disease, to inform doctors throughout the country of advances in the diagnosis, cure and treatment of heart diseases, and to improve facilities for the treatment of heart patients where the National Health Service is unable to help. 


\section{British Heart Foundation-Daphne Jackson Fellowships}

Purpose: To provide an opportunity for basic scientists to return to cardiovascular research at an established research institution in the United Kingdom after a career break of two years or more

Eligibility: Your eligibility and suitability are initially assessed using the information submitted to us in the CV and personal statement forms. If you do fit our eligibility criteria, one of our Fellowship Advisors will arrange an informal telephone interview with you to talk through your $\mathrm{CV}$, your career break, your desire to retrain, your field of interest and assess your future employment prospects

Type: Fellowship

Length of Study: Up to three years

Frequency: Annual

Country of Study: Any country

Application Procedure: 1. Applicants will need to approach and agree a plan of work with a potential academic sponsor as part of the application process. We are particularly interested in supporting applicants working in interdisciplinary research, but applicants working in single disciplines will be considered equally. 2. The Elizabeth Blackwell Institute will half-sponsor the Fellowship and the remaining funding will be secured by the Daphne Jackson Trust from an additional sponsor

Closing Date: 18 February

Funding: Private

Additional Information: The fellowship will be part-time for a fixed term of up to three years daphnejackson.org/wpcontent/uploads/2019/07/British-Heart-Foundation-DaphneJackson-Fellowship-2019.pdf

\section{For further information contact:}

The Daphne Jackson Trust, Department of Physics, University of Surrey, Guildford, Surrey, GU2 7XH, United Kingdom.

Email: djmft@surrey.ac.uk

\section{Career Re-entry Research Fellowships}

Purpose: To provide an opportunity to re-establish a career in cardiovascular science in an established research institution in the United Kingdom, after a break of more than one year

Eligibility: 1. Successful post-doc returning after a career break of one or more years. 2 . The candidate must have the support of a named senior investigator who will guarantee access to space and resources and provide scientific guidance for the duration of their fellowship. This individual should be named on the application form as a 'Supervisor' and provide an appropriate letter of support as part of the application. 3 . The fellowship may be taken up on a part-time employment basis, where appropriate, following discussion and agreement with us and the employing institution. For more information read about our Flexible working policies

Level of Study: Postdoctorate researcher

Type: Fellowship

Value: $£ 500$ per year

Length of Study: Up to 1 year full-time or up to 3 years parttime

Frequency: Varies

Country of Study: United Kingdom

Application Procedure: Application link for the grants are as follows: gms.bhf.org.uk/Pages/Default.aspx?ReturnUrl $=\%$ $252 \mathrm{f}$ layouts $\% 252$ fAuthenticate.aspx $\% 253 \mathrm{fSource} \% 253 \mathrm{~d} \%$ $252 \mathrm{f} \&$ Source $=\% 252 \mathrm{f}$

\section{Funding: Private}

Additional Information: For further information, visit the website www.bhf.org.uk www.bhf.org.uk/for-professionals/ information-for-researchers/what-we-fund/career-re-entryresearch-fellowship

\section{For further information contact:}

British Heart Foundation, Lyndon Place, 2096 Coventry Road, Sheldon, Birmingham, B26 3YU, United Kingdom.

Tel: (44) 2075540442

Email: gmsqueries@bhf.org.uk

\section{Clinical Research Leave Fellowships}

Purpose: To provide an opportunity for talented NHS staff to undertake dedicated PAs in research in a recognised United Kingdom centre of excellence in cardiovascular medicine Eligibility: Awards may include: 1. Reimbursement of reasonable costs to cover relinquished PAs. 2. Research consumables directly attributable to the project

Level of Study: Graduate

Type: Fellowship

Value: $£ 500$ per year

Length of Study: Up to 1 year full-time or up to 3 years parttime

Frequency: Annual

Country of Study: Any country

Application Procedure: Candidates may be interviewed and a decision on this will be reached by the Fellowships Committee (four meetings a year) after it has considered external peer review reports

Funding: Private 
Additional Information: www.bhf.org.uk/for-professionals/ information-for-researchers/what-we-fund/clinical-researchleave-fellowship

\section{For further information contact:}

180, Hampstead Road, London, NW1 7AW, United Kingdom.

Tel: (44) 2075540442

Email: gmsqueries@bhf.org.uk

\section{Clinical Study Grants}

Purpose: To provide an opportunity for talented NHS staff to undertake dedicated PAs in research in a recognised United Kingdom centre of excellence in cardiovascular medicine Eligibility: 1. The principal investigator will be a senior researcher working in an established research institution in the United Kingdom. She/he must have a strong track record of grant support, usually from us, and an internationally recognised research profile. 2. Any multicentre interventional clinical trial, while remaining under the scientific control of the principal investigator, should usually be managed by a United Kingdom CRC-registered Clinical Trials Unit (CTU) and should usually include a member of the CTU as a co-applicant or principal investigator unless there are clearly justified reasons for not doing so

Level of Study: Graduate

Type: Fellowship or Grant

Value: $£ 2,000$ per year

Length of Study: Usually up to 5 years, with regular progress reports, initially annual reports

Frequency: Every 5 years

Country of Study: Any country

Application Procedure: Once a preliminary application is approved you should submit a full application: 1. Read the information in How to apply. 2. Read about the SoECAT form. 3. Also read: Costing a clinical study. Excess treatment costs. Costing a clinical research imaging scan. Clinical Trials Units. Clinical Study Guidelines. Patient and public involvement. 4. Log onto the online application form. Application has to be completed through online procedurals

Closing Date: 1 April

Funding: Private

Additional Information: www.bhf.org.uk/for-professionals/ information-for-researchers/what-we-fund/clinical-study

\section{For further information contact:}

180 Hampstead Road, London, NW1 7AW, United Kingdom.

Tel: (44) 2075540442

Email: gmsqueries@bhf.org.uk

\section{Immediate Postdoctoral Basic Science Research Fellowships}

Purpose: To provide an opportunity for the most promising newly qualified postdoctoral researchers to make an early start in developing their independent cardiovascular research careers in an established institution in the United Kingdom

Eligibility: Candidates should be in the final year of their $\mathrm{PhD}$ studies or have no more than two years of postdoctoral research experience from the date of the $\mathrm{PhD}$ viva. Candidates must be able to show, by publications or otherwise, evidence of exceptional research ability. The fellowship should not be held in the institution where the $\mathrm{PhD}$ was carried out. Residency requirements do not apply

Level of Study: Postgraduate

Type: Fellowship

Value: Travel funding of up to $£ 500$ per year \& Housing contribution up to $£ 3,000$

Length of Study: 1.5 years

Country of Study: Any country

Application Procedure: The online application form must be completed by the applicant

Funding: Private

Additional Information: www.bhf.org.uk/for-professionals/ information-for-researchers/what-we-fund/immediate-postdoct oral-basic-science-research-fellowship

\section{For further information contact:}

Tel: (44) 2075540442

Email: gmsqueries@bhf.org.uk

\section{Intermediate Clinical Research Fellowships}

Purpose: To provide a career opportunity in an established research institution in the United Kingdom for individuals with an established research record who intend to become leaders in academic medical research

Eligibility: Successful PhD (or MD) plus NTN and at least two years completed specialist training, but usually no more than two years after CCT. NTN will be exchanged for NTN (A) on appointment, and the individual may progress to consultant level during the fellowship

Level of Study: Graduate

Type: Fellowships, operating grants

Value: Travel funding of up to $£ 500$ per year \& Housing contribution up to $£ 3,000$

Length of Study: 5 years duration

Frequency: Annual

Country of Study: Any country

Application Procedure: 1. Read the information in How to apply. 2. Read our commitment to Improving Support for 
Clinical Academics. If you are applying for funding for a clinical study, also read: 1 . Costing a clinical study. 2. Costing a clinical research imaging scan. 3. Clinical Trials Units. 4. Clinical Study Guidelines. 5. Log onto the online application form. Complete all the sections of the online application form following the instructions in the GMS User Guide. The online application must be completed by the applicant. Shortlisted candidates may be interviewed

Funding: Government

Additional Information: www.bhf.org.uk/for-professionals/ information-for-researchers/what-we-fund/intermediate-clinicalresearch-fellowships

\section{For further information contact:}

Research Funds Department, British Heart Foundation, Greater London House, 180 Hampstead Road, London, NW1 7AW, United Kingdom.

Tel: (44) 2075540442

Email: gmsqueries@bhf.org.uk

\section{New Horizon Grants}

Purpose: To encourage scientists from outside traditional cardiovascular biology to engage in cardiovascular research and bring novel expertise to the field, and to develop new technologies, models or methodologies

Eligibility: 1. The principal investigator will be a senior researcher working in an established research institution in the United Kingdom. He/she must have a strong track record of project grant support and an internationally recognised research profile. 2. The principal investigator or co-applicant (s) should include researcher(s) with a strong track record of relevant cardiovascular research. 3 . The principal investigator or co-applicant(s) should include researcher(s) from outside traditional cardiovascular biology, who do not have extensive existing collaborations with cardiovascular researchers

\section{Level of Study: Graduate}

Type: Grant

Value: Up to $£ 300,000$ and up to three years \& Travel funding of up to $£ 2,000$ per year

Frequency: Every 3 years

Country of Study: Any country

Application Procedure: Kindly check the website for further information. www.bhf.org.uk/for-professionals/informationfor-researchers/what-we-fund/new-horizon-grants

Funding: Private

Additional Information: You will be asked to attach a single PDF document to your online application form containing the following information: 1. For resubmissions, include an unedited copy of the original feedback followed by a detailed response, limited to 3 sides of A4, explaining how the revised application has changed from the original submission. 2. Abstract of the proposed investigation in 200 words or less. 3. Background to the project and pilot data. 4. Original hypothesis. 5. Experimental details and design of proposed investigation. 6. Power calculations. 7. Expected value of results. 8. List of references relevant to the proposed project www.bhf.org.uk/for-professionals/information-for-researchers/ what-we-fund/new-horizon-grants

\section{For further information contact:}

180 Hampstead Road, London, NW1 7AW, United Kingdom.

Tel: (44) 2075540442

Email: gmsqueries@bhf.org.uk

\section{Non-Clinical PhD Studentships}

Purpose: To allow talented students to complete a $\mathrm{PhD}$ in cardiovascular science in an established research institution in the United Kingdom

Eligibility: The application must be made by an established investigator who will be the supervisor and may be for a named or unnamed student. The primary supervisor must devote a minimum of $10 \%$ of their time to supervising the student and a second supervisor should also be included. Extra scrutiny will be given to applications from institutions in receipt of a BHF Research Excellence award or from supervisors named on a BHF 4 year PhD Scheme. These applications will require additional justification and should be for named students only. The BHF does not provide 'topup' funding for existing PhD studentships supported by other grant giving organisations, which are incompletely funded

Level of Study: Graduate, Postgraduate

Type: Studentship and scholarship

Value: $£ 10,000$ per year

Frequency: Every 3 years

Country of Study: Any country

Application Procedure: Apply through online mode post registration on the below link. gms.bhf.org.uk/Pages/ Default.aspx?ReturnUrl=\%252f_layouts $\% 252$ fAuthenticate. aspx $\% 253 f$ Source $\% 253 \mathrm{~d} \% 252 \mathrm{f} \&$ Source $=\% 252 \mathrm{f}$

Funding: Private

Additional Information: www.bhf.org.uk/for-professionals/ information-for-researchers/what-we-fund/phd-studentships

\section{For further information contact:}

Tel: (44) 2075540442

Email: gmsqueries@bhf.org.uk 


\section{Research Training Fellowships for Nurses and Allied Health Professionals}

Purpose: To provide a foundation in research training in an established research institution in the United Kingdom for nurses and allied health professionals, leading to the award of a $\mathrm{PhD}$.

Eligibility: The named student should usually hold a good quality Masters degree or equivalent. 1. Students who have started a $\mathrm{PhD}$ (or equivalent) may be eligible to apply for a Research Training Fellowship, but the application must be received within 6 months of having registered for their PhD In these circumstances, the proposed start date for the Research Training Fellowship should also be no more than 12 months (or full-time equivalent) from the date of registration for the degree. 2. If the fellowship is taken up on a full-time research basis, we recognise that part of the time (ideally no more than $20 \%$ though sometimes more if it can be argued that the research directly involves their patients) may be spent on patient care. 3. The fellowship may be taken up on a parttime employment basis, where appropriate, following discussion and agreement with us and the employing institution. For more information, read about our Flexible working policies

Level of Study: Postgraduate

Type: Fellowship

Value: $£ 10,000$ per year

Frequency: 5 years

Country of Study: Any country

Application Procedure: Check through the website link. www.bhf.org.uk/for-professionals/information-for-researchers/ what-we-fund/research-training-fellowships-for-nurses-andallied-health-professionals

Closing Date: 22 April

Funding: Foundation

Additional Information: www.bhf.org.uk/for-professionals/ information-for-researchers/what-we-fund/research-trainingfellowships-for-nurses-and-allied-health-professionals

\section{For further information contact:}

Email: research@bhf.org.uk

\section{Travel Fellowships}

Purpose: To enable a postdoctoral researcher to undertake a visit to a distinguished laboratory abroad, either for a short period of up to six months to acquire specialist knowledge or expertise, or for a longer period to carry out a research project that can not be done in United Kingdom

Eligibility: Usually more than three years postdoctoral experience, but applicants with less postdoctoral experience are also eligible to apply. Applicant must hold a post in the United
Kingdom and a guaranteed post to return to after the fellowship

Level of Study: Postdoctorate

Type: Fellowship

Frequency: Annual

Country of Study: Any country

Application Procedure: 1. Read the information in How to apply. 2. Log onto the online application form. 3. Complete all the sections of the online application form following the instructions in the GMS User Guide. 4. Ensure the named Supervisor in the application form is your United Kingdom Supervisor

Funding: Private

Additional Information: www.bhf.org.uk/for-professionals/ information-for-researchers/what-we-fund/travel-fellowships

\section{For further information contact:}

Email: research@bhf.org.uk

\section{British Institute at Ankara (BIAA)}

10 Carlton House Terrace, London, SW1Y 5AH, United Kingdom.

Tel: $\quad$ (44) 2079695204

Email:_biaa@britac.ac.uk

Website: www.biaa.ac.uk

Contact: Claire McCafferty, London Administrator

BIAA aims to support, promote, facilitate, and publish British research focused on Turkey and the Black Sea littoral in all academic disciplines within the arts, humanities, and social sciences and to maintain a centre of excellence in Ankara focused on the archaeology and related subjects of Turkey.

\section{British Institute at Ankara Research Scholarship}

Purpose: To conduct their own research at doctoral level Eligibility: Open to candidates who hold a Master's degree and have a demonstrable connection to United Kingdom academia

Level of Study: Postgraduate, Research

Type: Research scholarship

Value: $£ 800$ per month and the cost of one return flight between the United Kingdom and Turkey

Length of Study: 9 months

Frequency: Annual

Country of Study: Turkey 
Application Procedure: Deadline for applications is mid-September. Check website for further details

Closing Date: September

\section{For further information contact:}

British Institute at Ankara, Çankaya, Atatürk Blv No:154, 06690 Çankaya/Ankara, Turkey.

Fax: (44) 2079695401

\section{Martin Harrison Memorial Fellowship}

Purpose: To assist junior Turkish archaeologists, who are not able to take advantage of travelling, working in any area of the archaeology of Anatolia from Prehistory to the Ottoman period, to visit the United Kingdom, especially Oxford, in connection with their research work

Eligibility: Open to Turkish citizens residing in Turkey who have completed at least 2 years of postgraduate research and at most held a doctorate for 5 years, working in any area of the archaeology of Anatolia (from the Prehistoric to the Ottoman period)

Level of Study: Doctorate, Postgraduate, Research

Type: Short-term fellowship

Value: $£ 1,500$ and travel expenses from and to Turkey

Length of Study: 6-13 weeks

Frequency: Annual

Study Establishment: University of Oxford

Country of Study: United Kingdom

Application Procedure: Completed applications, including a curriculum vitae, should be sent to the Turkey address

Closing Date: 31 March

Funding: Foundation

Contributor: Martin Harrison Fund for living expenses and British Institute at Ankara (BIAA) for travel

Additional Information: The selection will be made on the basis of the applicant's academic record, coherent research proposal, ability to benefit from libraries and scholars in Oxford, and a working knowledge of spoken and written English biaa.ac.uk/opportunities/item/name/martin-harrisonmemorial-fund-fellowship

\section{For further information contact:}

The British Institute at Ankara, 24 Tahran Caddesi, Kavaklidere, TR-06700 Ankara, Turkey.

Tel: $\quad$ (90) 3124275487

Fax: (90) 3124280159

Email: ggirdivan@biaatr.org

\section{British Institute in Eastern Africa}

British Institute in Eastern Africa, Laikipia Road, Kileleshwa, Nairobi, PO Box 30710 - 00100 GPO, Kenya.

Tel:

(254) 208155186

Email:_office@biea.ac.uk

Website: www.biea.ac.uk

Contact: Dr David Anderson, Director

The British Institute in Eastern Africa (BIEA) exists to promote research in the humanities and social sciences. BIEA is based in Nairobi, but supports work across Eastern Africa, and is one of the schools and institutes supported by the British Academy.

\section{British Institute in Eastern Africa Minor Grants}

Purpose: To assist with the costs of research projects in Eastern Africa

Eligibility: Open to applicants from United Kingdom and Eastern Africa

Level of Study: Postgraduate

Type: Grant

Value: Up to $£ 1,000$

Study Establishment: The British Institute in Eastern Africa Application Procedure: Application forms can be downloaded from the BIEA website

No. of awards offered: 45

Closing Date: 31 January

Funding: Government

Contributor: British Academy

No. of awards given last year: 22

No. of applicants last year: 45

Additional Information: Applicants must contact the Director for further information on relevant topics likely to receive support. Those awarded grants will be required to keep the Institute regularly informed of the progress of their research, to provide a preliminary statement of accounts within 18 months of the award dates and to provide the Institute with copies of all relevant publications. They are encouraged to discuss with the Director the possibility of publishing their results in the Institute's journal, Azania. Results for the Minor Grants Award may be expected within 2 months of either 30 May or 30 November. Those awarded grants are required to become members of the BIEA www.biea.ac.uk/

\section{For further information contact:}

Email: pjlane@insightkenya.com 


\section{British Medical Association (BMA)}

BMA Research Grants, BMA House, Tavistock Square, London, WC1H 9JP, United Kingdom.

Tel: $\quad$ (44) 2073836341

Email: info.sciencegrants@bma.org.uk

Website: www.bma.org.uk

The BMA is a voluntary professional association with over two-thirds of practising United Kingdom doctors in membership and an independent trade union dedicated to protecting individual members and the collective interests of doctors.

\section{Helen H Lawson Research Grant}

Purpose: To promote research into novel technologies and IT to assist in patient care, primary care or public health

Eligibility: Open to registered medical practitioners in the United Kingdom who are BMA members

Level of Study: Research

Type: Research grant

Value: $£ 65,000$

Length of Study: 3 years

Frequency: Annual

Country of Study: United Kingdom

Application Procedure: Applicants must complete an online application form. Applications that do not comply with all of the above terms and conditions will be rejected without exception

No. of awards offered: 10

Closing Date: 6 March

Funding: Trusts

No. of awards given last year: 1

No. of applicants last year: 10

Additional Information: Please check at bma.org.uk/ developing-your-career/portfolio-career/research-grants/rese arch-grants-details/research-grants-roscoe www.bmafound ationmr.org.uk/media/1209/helen-h-lawson-2020.pdf

\section{For further information contact:}

Corporate Development Directorate, British Medical Association, Tavistock Square, London, WC1H 9JP, United Kingdom.

Tel: (44) 2073836341

Email: researchgrants@bma.org.uk

\section{Josephine Lansdell Research Grant}

Purpose: To assist and support research into the field of heart diseases

Eligibility: Open to registered medical practitioners in the United Kingdom who are BMA members

Level of Study: Research

Type: Research grant

Value: $£ 65,000$

Length of Study: 3 years

Frequency: Annual

Country of Study: Any country

Application Procedure: Applicants must complete an online application form. Applicants are required to upload (PDF format) two references during the online application process. Please note each reference MUST bear the electronic (scanned) signature of the referee. For joint applications, each applicant requires two referees (these can be the same for both applicants)

No. of awards offered: 10

Closing Date: 6 March

Funding: Trusts

No. of awards given last year: 1

No. of applicants last year: 10

Additional Information: Please check at bma.org.uk/ developing-your-career/portfolio-career/research-grants/rese arch-grants-details/research-grants-lansdell www.bmafound ationmr.org.uk/media/1210/josephine-lansdell-2020.pdf

\section{For further information contact:}

Corporate Development Directorate, British Medical Association, Tavistock Square, London, WC1H 9JP, United Kingdom.

Tel: (44) 2073836341

Email: researchgrants@bma.org.uk

\section{Vera Down Research Grant}

Purpose: To assist and support research

Eligibility: Open to registered medical practitioners in the United Kingdom who are BMA members

Level of Study: Research

Type: Research grant

Value: $£ 55,000$

Length of Study: 3 years

Frequency: Annual

Country of Study: United Kingdom

Application Procedure: Applicants must complete an online application form

No. of awards offered: 10 
Closing Date: 15 March

Funding: Trusts

No. of awards given last year: 1

No. of applicants last year: 10

Additional Information: Please check at bma.org.uk/ developing-your-career/portfolio-career/research-grants/rese arch-grants-details/research-grants-down bmafoundationmr. org.uk/media/1143/vera-down-2019.pdf

\section{British School at Athens}

52 Souedias Street, GR-10676 Athens, Greece.

Tel: (30) 2111022800

Email: admin@bsa.ac.uk

Website: www.bsa.gla.ac.uk

Contact: Dr Chryssanthi Papadopoulou, Assistant Director

The British School at Athens promotes research into the archaeology, architecture, art, history, language, literature, religion and topography of Greece in ancient, medieval and modern times. It consists of the Library, Fitch Laboratory for Archaeological Science, Archive, Museum, hostel and a second base at Knossos for research and fieldwork.

\section{Hector and Elizabeth Catling Bursary}

Purpose: To assist travel, maintenance costs and for the purchase of scientific equipments. Its aim is to encourage excellence in archaeological drawing, including the preparation of finished drawings for publication

Eligibility: Open to researchers of British, Irish or Commonwealth nationality

Level of Study: Doctorate, Postdoctorate, Postgraduate, Research

Type: Bursary

Value: $£ 500$ per bursary to assist with travel and maintenance costs incurred in fieldwork, to pay for the use of scientific or other specialized equipment in or outside the laboratory in Greece or elsewhere and to buy necessary supplies

Frequency: Annual

Study Establishment: The British School at Athens

Country of Study: Any country

Application Procedure: 1. Applicants must submit a curriculum vitae and state concisely the nature of the intended work, a breakdown of budget, the amount requested from the Fund and how this will be spent. 2. Applications should include two sealed letters of reference. Bursary holders must submit a short report to the Committee upon completion of the project

Closing Date: 15 May

Funding: Private

Additional Information: The bursary is not intended for publication costs, and cannot be awarded to an excavation or field survey team www.bsa.ac.uk/awards/research-awards/ the-hector-and-elizabeth-catling-bursary/

\section{For further information contact:}

Email: assistant.director@bsa.ac.uk

\section{The Elizabeth Catling Memorial Fund for Archaeological Draughtsmanship}

Purpose: To encourage excellence in archaeological drawing, including the preparation of finished drawings for publication. It is hoped that awards will help individuals to improve their standards of draughtsmanship and also enable the preparation of a larger number of drawings, of higher quality, than might otherwise have been possible

Eligibility: Individual applicants must show that drawings are an essential part of their research. Furthermore, although not a precondition, it is hoped that they may be draughtsmen themselves. Applications from project directors, who may also apply during the course of a field campaign, are limited to unexpected expenses that are not provided for in the project's budget, such as extra maintenance costs to enable a draughtsman to draw unforeseen material and finds

Level of Study: Predoctorate

Type: Funding support

Value: $£ 500$

Frequency: Annual

Application Procedure: Candidates should submit letters of application to the School's London office by post in four copies or by email. Letters should not be longer than two pages and should include a statement of the purposes of the application and a budget and timetable for the proposed work, together with the name and address of a referee whom the awarding panel(s) may consult. Applications may be made for but are not limited to, grants towards the maintenance costs of longer stays at museums and other study centres so as to achieve work that would not otherwise have been attempted. Recipients of awards must have been admitted as Students of the School for the appropriate Session before receiving their grants, and must submit a short report on the use of the grant to the London office

Closing Date: 24 April

Additional Information: The Fund does not support printing expenses, or site drawings such as plans and sections, or computer graphics www.bsa.ac.uk/awards/research-awards/ 
the-elizabeth-catling-memorial-fund-for-archaeological-draught manship/

\section{For further information contact:}

British School at Athens, Senate House, Malet Street, London, WC1E 7HU, United Kingdom.

Email: bsa@sas.ac.uk

\section{The John Morrison Memorial Fund for Hellenic Maritime Studies}

Purpose: To further research into all branches of Hellenic maritime studies of any period

Type: Funding support

Value: $£ 500$

Frequency: Annual

Application Procedure: Candidates should submit letters of application to the School's London office by post in four copies or by email. Letters should not be longer than two pages and should include a statement of the purposes of the application and a budget and timetable for the proposed work, together with the name and address of a referee whom the awarding panel(s) may consult. Applications may be made for but are not limited to, grants towards the maintenance costs of longer stays at museums and other study centres so as to achieve work that would not otherwise have been attempted. Recipients of awards must have been admitted as Students of the School for the appropriate Session before receiving their grants, and must submit a short report on the use of the grant to the London office Closing Date: 30 April

Additional Information: Grants may also be available from the Fund for buying maritime books and journals for the School's Library www.bsa.ac.uk/awards/research-awards/thejohn-morrison-memorial-fund-for-hellenic-maritime-studies/

\section{For further information contact:}

British School at Athens, Senate House, Malet Street, London, WC1E 7HU, United Kingdom.

Email: assistant.director@bsa.ac.uk

\section{The Richard Bradford McConnell Fund for Landscape Studies}

Purpose: To assist research in the interaction of place and people in Greece and Cyprus at any period(s)

Type: Funding support

Value: $£ 400$

Frequency: Annual
Application Procedure: Candidates should submit letters of application to the School's London office by post in four copies or by email. Letters should not be longer than two pages and should include a statement of the purposes of the application and a budget and timetable for the proposed work, together with the name and address of a referee whom the awarding panel(s) may consult. Applications may be made for but are not limited to, grants towards the maintenance costs of longer stays at museums and other study centres so as to achieve work that would not otherwise have been attempted. Recipients of awards must have been admitted as Students of the School for the appropriate Session before receiving their grants, and must submit a short report on the use of the grant to the London office

Closing Date: 24 April

Contributor: Richard Bradford Trust

Additional Information: www.bsa.ac.uk/awards/researchawards/the-richard-bradford-mcconnell-fund-for-landscapestudies/

\section{For further information contact:}

British School at Athens, Senate House, Malet Street, London, WC1E 7HU, United Kingdom.

Email: school.administrator@bsa.ac.uk

\section{To support research in the prehistory of the Aegean and its connections with the East Mediterranean}

Purpose: To support research in the prehistory of the Aegean and its connections with the East Mediterranean Eligibility: Preference may be given to younger Students Type: Funding support

Value: $£ 500$ are available for the expenses (including, but not limited to, attending conferences to present papers, photography, and travel to museums and sites)

Application Procedure: Candidates should submit letters of application to the School's London office by post in four copies or by email. Letters should not be longer than two pages and should include a statement of the purposes of the application and a budget and timetable for the proposed work, together with the name and address of a referee whom the awarding panel(s) may consult. Applications may be made for but are not limited to, grants towards the maintenance costs of longer stays at museums and other study centres so as to achieve work that would not otherwise have been attempted. Recipients of awards must have been admitted as Students of the School for the appropriate Session before receiving their grants, and must submit a short report on the use of the grant to the London office 
Closing Date: 1 April

Additional Information: Check website for more details

\section{For further information contact:}

British School at Athens, Senate House, Malet Street, London, WC1E 7HU, United Kingdom.

Email: bsa@sas.ac.uk

\section{Visiting Fellowships}

Purpose: Visiting Fellowships at the British School at Athens are offered for 2-3 months for research in any branch of the arts or social sciences related to Greece. The Fellowship is non-stipendiary, but accommodation and airfare are provided Eligibility: The Fellow is required to submit a report covering their research and their time at the School to the School's Council

Level of Study: Postgraduate

Type: Fellowship

Frequency: Annual

Country of Study: Any country

Application Procedure: The School Administrator, school. administrator@bsa.ac.uk

Closing Date: 19 April

Funding: Private

Additional Information: www.britishcouncil.in/study-uk/ scholarships/charles-wallace-trust/visiting-fellows

\section{For further information contact:}

The British School at Athens, 52 Souedias Street, GR-10676 Athens, Greece.

Fax: (30) 2111022803

Email: school.administrator@bsa.ac.uk

\section{British School at Rome (BSR)}

The BSR at the British Academy, 10 Carlton House Terrace, London, SW1Y 5AH, United Kingdom.

Tel: $\quad$ (44) 2079695202

Email: bsr@britac.ac.uk

Website: www.bsr.ac.uk

Contact: Natalie Arrowsmith, Communications Manager

The British School at Rome (BSR) is an interdisciplinary research centre for the humanities, visual arts and architecture. Each year, the School offers a range of awards in its principal fields of interest. These interests are further promoted by lectures, conferences, publications, exhibitions, archaeological research and an excellent reference library.

\section{Abbey Scholarship in Painting}

Purpose: To give exceptionally promising early career painters the opportunity to work in Rome

Eligibility: offers one early-career artist a full academic year (October to June) at the British School at Rome

Level of Study: Doctorate, Graduate, Postdoctorate, Postgraduate

Type: Scholarship

Value: $€ 800$

Length of Study: 9 months

Frequency: Annual

Study Establishment: The British School at Rome

Country of Study: Italy

Application Procedure: We are now open for applications to the Abbey Fellowships and Scholarship until midday, 20th January 2020.

Closing Date: 20 January

Funding: Private

Contributor: The Abbey Council

No. of awards given last year: 1

Additional Information: Check website for more details abbey.org.uk/

\section{For further information contact:}

Abbey Awards, 1 St Lukes Court, 136 Falcon Road, London, SW11 2LP, United Kingdom.

Email: contact@abbey.org.uk

\section{Giles Worsley Travel Fellowship}

Purpose: To enable an architect or architectural historian to spend 3 months in Rome studying an architectural topic of his choice

Eligibility: Open to those who are of British nationality or who have been living and studying in Britain for at least the last 3 years

Level of Study: Postdoctorate, Postgraduate, Professional development

Type: Fellowship

Value: Approx. $€ 700$ per month plus full board and lodging at the British School at Rome 
Length of Study: 3 months

Frequency: Annual

Study Establishment: The British School at Rome

Country of Study: Italy

Application Procedure: Applicants must submit a curriculum vitae, a statement indicating the subject of their proposal and arrange for two references to be sent

Closing Date: February

Funding: Private

No. of awards given last year: 1

Additional Information: www.bsr.ac.uk/awards/architectureawards-ii\#giles

\section{Paul Mellon Centre Rome Fellowship}

Purpose: To assist research on grand tour subjects or on Anglo-Italian cultural and artistic relations

Eligibility: Open to established scholars in the United Kingdom, United States or elsewhere. Applicants should be fluent in Italian

Level of Study: Doctorate, Graduate, Postdoctorate, Postgraduate, Professional development, Research

Type: Fellowship

Value: Full board at the British School at Rome. For independent scholars, the fellowship offers a stipend of $€ 6,000$ plus travel to and from Rome. For scholars in full-time university employment, the fellowship offers an honorarium of $€ 2,000$, travel to and from Rome and a sum of $€ 6,000$ towards replacement teaching costs for a term at the Fellow's home institution

Length of Study: 3 months

Frequency: Annual

Study Establishment: The British School at Rome

Country of Study: Italy

Application Procedure: Applicants must contact the Paul

Mellon Centre for Studies in British Art for details

Closing Date: January

Funding: Private

Contributor: The Paul Mellon Centre for Studies in British

Art

No. of awards given last year: 1

Additional Information: Please check website for more details www.bsr.ac.uk/paul-mellon-centre-rome-fellowshipdeadline-approaching

\section{For further information contact:}

The Paul Mellon Centre for Studies in British Art, 16 Bedford Square, London, WC1B 3JA, United Kingdom.

Email: grants@paul-mellon-centre.ac.uk

\section{British Society for Antimicrobial Chemotherapy}

British Society for Antimicrobial Chemotherapy, Griffin House, 53 Regent Place, Birmingham, B1 3NJ, United Kingdom.

Tel:

Website: www.bsac.org.uk

Contact: Ms Tracey Guise, Executive Director

BSAC is an inter-professional organization with 40 years of experience and achievement in antibiotic education, research and leadership. It is dedicated to saving lives through appropriate use and development of antibiotics now and in the future.

\section{British Society for Antimicrobial Chemotherapy Overseas Scholarship}

Purpose: Overseas Scholarships are to enable workers from other countries the opportunity to work in United Kingdom Departments for up to 6 months

Level of Study: Postgraduate, Professional development

Type: Scholarship

Value: $£ 1,000$ per calendar month for up to 6 months. The host institution will receive a consumables grant of $£ 200$ per calendar month for the duration of the scholarship. The Society will reimburse the cost of return air fares and travel via the most economical route. Candidates will be asked to seek approval of travel costs in advance

Length of Study: 6 months

Frequency: Annual

Country of Study: United Kingdom

Application Procedure: Successful applicants are required to submit a 500-word written report to the Secretary of the Grants Committee on completion of their project, and to forward details of any publications arising from the work undertaken. Applications for Overseas Scholarships should be made to the Society's HQ using the form provided on the BSAC website

Closing Date: 1 December

Funding: Foundation

Additional Information: Excludes applicants from United Kingdom www.bsac.org.uk/funding/overseas-scholarship/

\section{For further information contact:}

Email: tguise@bsac.org.uk 


\section{British Society for Middle Eastern Studies}

Institute for Middle Eastern \& Islamic Studies, Durham University, Al-Qasimi Building, Elvet Hill Road, Durham, DH1 3TU, United Kingdom.

Tel: $\quad$ (44) 1913345179

Email: a.1.haysey@durham.ac.uk

Website: www.brismes.ac.uk/

\section{Master's Scholarship}

Purpose: BRISMES offers an annual Master's scholarship for taught Master's study at a United Kingdom institution. The Master's programme can be in any discipline but should include a majority component specifically relating to the Middle East

Eligibility: Preference will be given to candidates resident in the European Union, and to institutions who are members of BRISMES

Level of Study: Doctorate

Type: Scholarship

Value: $£ 1,200$

Frequency: Annual

Country of Study: United Kingdom

Application Procedure: Applications should be forwarded by the Director of the Master's programme concerned, to the BRISMES Administrative Office, and should include: a supporting statement from the course Director not exceeding 500 words; the programme syllabus; a statement by the candidate not exceeding 500 words; the candidate's curriculum vitae and transcript of previous academic results; two academic references. Applications should be sent to Institute for Middle Eastern \& Islamic Studies

Closing Date: 31 March

Funding: Foundation

Additional Information: Please check website for more details www.birmingham.ac.uk/postgraduate/funding/ BRISMES-Scholarships.aspx

\section{For further information contact:}

Email: a.1.haysey@dur.ac.uk

\section{The Abdullah Al-Mubarak Al-Sabah Foundation BRISMES Scholarships}

Purpose: The purpose of the scholarships is to encourage more people to pursue postgraduate studies in disciplines related to the Middle East in British universities
Eligibility: To qualify you must be a paid-up member of BRISMES (student membership suffices) but the time you apply

Level of Study: Postgraduate

Type: Scholarship

Value: $£ 2,000$

Length of Study: 1 academic year

Frequency: Annual

Country of Study: United Kingdom

Application Procedure: To qualify applicants must fulfil the following conditions: 1 . be registered at any UK university, 2. be a paid-up student member of BRISMES at the time of application, 3. submit an application of 600 - 1000 words, by E-mail to the BRISMES research committee This should include a sketch of the overall research topic, and a description of the purpose for which the grant would be used, 4. obtain a brief supporting statement from their supervisor

Funding: Foundation

Additional Information: www.brismes.ac.uk/student-area/ the-abdullah-mubarak-brismes-scholarshp

\section{For further information contact:}

Email: a.1.haysey@dur.ac.uk

\section{British Veterinary Association}

7 Mansfield Street, London, W1G 9NQ, United Kingdom.

Tel: (44) 2076366541

Email: bvahq@bva.co.uk

Website: www.bva.co.uk

The British Veterinary Association's chief interests are the standards of animal health and veterinary surgeons' working practices. The organization's main functions are the development of policy in areas affecting the profession, protecting and promoting the profession in matters propounded by government and other external bodies and the provision of services to members.

\section{Harry Steele-Bodger Memorial Travelling Scholarship}

Subjects: Veterinary science and agriculture.

Purpose: To further the aims and aspirations of the late Harry Steele-Bodger.

Eligibility: Open to graduates of veterinary schools in the UK or the Republic of Ireland who have been qualified for not 
more than 3 years, and to penultimate or final-year students at those schools.

Level of Study: Graduate, Postgraduate

Type: Scholarship

Value: Approx. £1,100

Frequency: Annual

Study Establishment: A veterinary or agricultural research institute or some other course of study approved by the governing committee

Country of Study: United Kingdom

Application Procedure: Applications can be submitted online www.bva.co.uk/Membership-and-benefits/Students/ Travel-grants-for-students/

No. of awards offered: 1 or 2

Closing Date: 3 May

Funding: Private

No. of awards given last year: 1

No. of applicants last year: 5

Additional Information: www.bva.co.uk/membership/bvastudent-membership/travel-grants-for-vet-students/

\section{For further information contact:}

See online application.

Tel: (44) 2079086340

Email: helenac@bva.co.uk

\section{Broadcast Education Association}

613 Kane Street, Mount Pleasant, MI 48858, United States of America.

Tel: $\quad$ (1) 9897739370

Email: orlik1pb@cmich.edu

Website: www.beaweb.org

Contact: Dr Peter Orlik, Scholarship Chair

\section{Abe Voron Award}

Purpose: Study for a career in radio at a BEA-member institution

Eligibility: 1. Must be a graduate student, 2. Must attend a university or a four-year college, 3 . Must not be attending high school currently, 4. Must study full-time, 5. Restricted to students studying TV/Radio Broadcasting

Level of Study: Graduate, Undergraduate

Type: Scholarship

Value: US $\$ 3,000$

Length of Study: One full academic year

Frequency: Annual
Country of Study: Any country

Application Procedure: The application MUST be typed to be considered. Keep an additional copy for your files. Remember to date and sign the form on the last page. Applications not typed and signed will be disqualified. Each copy of the application MUST be collated and securely stapled. The application asks for personal and academic data and transcripts, media and other experience, a written statement of goals, and supportive statements from two references, at least one of which must be an electronic media faculty member

No. of awards offered: 26

Closing Date: 12 October

Funding: Private

Contributor: Abe Voron Committee

No. of awards given last year: 3

No. of applicants last year: 26

Additional Information: www.petersons.com/scholarship/ abe-voron-award-111_219381.aspx

\section{For further information contact:}

613 Kane St, Mt. Pleasant, MI 48858, United States of America.

Tel: (1) 9897739370

\section{John Bayliss Award}

Purpose: Study toward a career in Radio at a Broadcast Education Association member institution.

Eligibility: 1. Must be a graduate student, 2. Must attend a university or a four-year college, 3 . Must not be attending high school currently 4 . Must study full-time, 5 . Restricted to students studying TV/Radio Broadcasting

Level of Study: Graduate, Undergraduate

Type: Scholarship

Value: US\$2,500

Length of Study: Full-time for one academic year

Frequency: Annual

Country of Study: Any country

Application Procedure: The application MUST be typed to be considered. Keep an additional copy for your files. Remember to date and sign the form on the last page. Applications not typed and signed will be disqualified. Each copy of the application MUST be collated and securely stapled. The application asks for personal and academic data and transcripts, media and other experience, a written statement of goals, and supportive statements from two references, at least one of which must be an electronic media faculty member

No. of awards offered: 26

Closing Date: 12 October

Funding: Private 
Contributor: John Bayliss Foundation

No. of awards given last year: 1

No. of applicants last year: 26

Additional Information: www.petersons.com/scholarship/ john-bayliss-award-111_219383.aspx

For further information contact:

613 Kane St, Mt. Pleasant, MI 48858, United States of America.

Tel: (1) 9897739370

\section{Library of American Broadcasting Foundation Award}

Purpose: Support for a graduate student focusing on the study of broadcast history

Eligibility: graduate student focusing on broadcast history

Level of Study: Graduate

Type: Scholarship

Value: US\$3,000

Length of Study: One full academic year

Frequency: Annual

Country of Study: Any country

Application Procedure: see and fill out application found on BEA website www.beaweb.org

No. of awards offered: 5

Closing Date: 12 October

Funding: Foundation

Contributor: Library of American Broadcasting Foundation

No. of awards given last year: 1

No. of applicants last year: 5

Additional Information: www.beaweb.org/wp/?page_id=2431

\section{Peter B. Orlik Scholarship}

Purpose: Study by juniors, seniors or graduate students at a BEA member institution

Eligibility: Any junior, senior or graduate student at a BEA member institution

Level of Study: Graduate, Undergraduate

Type: Scholarship

Value: US $\$ 3,000$

Length of Study: One full academic year

Frequency: Annual

Country of Study: Any country

Application Procedure: See BEA website www.beaweb.org No. of awards offered: 45

Closing Date: 12 October

Funding: Private

Contributor: Broadcast Education Association
No. of awards given last year: 1

No. of applicants last year: 45

Additional Information: bigfuture.collegeboard.org/scholar ships/peter-b-orlik-scholarship

\section{Richard Eaton Award}

Purpose: Given for study of electronic media by juniors, seniors, and graduate students

Eligibility: Junior, senior or graduate student at a BEA member institution

Level of Study: Graduate, Undergraduate

Type: Scholarship

Value: US $\$ 2,500$

Length of Study: 1 academic year - full-time

Frequency: Annual

Country of Study: Any country

Application Procedure: See and complete application on BEA website www.beaweb.org

No. of awards offered: 45

Closing Date: 12 October

Funding: Private

Contributor: Richard Eaton Foundation

No. of awards given last year: 1

No. of applicants last year: 45

Additional Information: www.unigo.com/scholarships/bymajor/advertising-scholarships/richard-eaton-award/1004553

\section{Vincent T. Wasilewski Award}

Purpose: For graduate study of electronic media at a BEA member institution

Eligibility: Any full-time graduate student at a BEA member institution

Level of Study: Graduate

Type: Scholarship

Value: US $\$ 4,000$

Length of Study: One academic year

Frequency: Annual

Country of Study: Any country

Application Procedure: See and complete application found at BEA website www.beaweb.org

No. of awards offered: 20

Closing Date: 12 October

Funding: Private

Contributor: Patrick Communications

No. of awards given last year: 1

No. of applicants last year: 20

Additional Information: www.unigo.com/scholarships/bymajor/advertising-scholarships/vincent-t-wasilewski-award/ 1004552 


\section{Brunel University}

Kingston Lane, Uxbridge, Middlesex, UB8 3PH, United Kingdom.

Tel: (44) 1895274000

Email:_admissions@brunel.ac.uk

Website: www.brunel.ac.uk

Contact: Professor Adrian Woods, Dean of the Graduate School

\section{Brunel Santander International Scholarship}

Purpose: Brunel University London is pleased to offer a prestigious package of scholarships for International students. The Brunel Santander International Scholarship 2020/2021 is for self-funded students. Brunel University London offers candidates to help support international students.

Eligibility: 1. The candidate must for reasons related to fees, classified in the category "overseas" and financed from own resources (unfunded). 2. Applicants who are unsure of the status of their fees should note that Brunel uses the information provided in their application form to evaluate the fee status according to the rules established by the UK Government. 3. Applicants must have the opportunity to study in a post-graduate program or postdoctoral research program in September 2020 and must complete the corresponding fellowship application within the required timeframe. 4. Candidates must have accepted their course offer before the scholarship deadline.

Level of Study: Postgraduate

Type: Scholarship

Value: $£ 3,000$

Length of Study: 1 year

Frequency: Annual

Country of Study: Any country

Application Procedure: To apply for a Brunel Santander International Scholarship, candidates must fill out the application form, which requires a personal declaration within the prescribed deadlines. Supported Documents: As part of the application, the applicant must provide a personal statement.

Closing Date: 30 April

Funding: International office

Additional Information: worldscholarshipforum.com/ brunel-santander-international-scholarship/

\section{For further information contact:}

Email: scholarships@brunel.ac.uk

\section{Budapest International Music Competition}

Philharmonia Budapest, Alkotmany u.31 1/2, H-1054 Budapest, Hungary.

Tel: $\quad$ (36) 12661459,3024961

Email:_liszkay.maria@hu.inter.net

Contact: Ms Maria Liszkay, Secretary

The Budapest Music Competition has been held since 1933 . Competitions in different categories alternate annually.

\section{International Carl Flesch Violin Competition}

Purpose: To promote European violinists

Eligibility: Competitors should possess at least 2 years of musical study in Europe and should be born on or after 1 January, 1980

Type: Competition

Value: $€ 4,000$ net (first prize), $€ 3,000$ net (second prize) and $€ 2,000$ net (third prize)

Country of Study: Hungary

Application Procedure: Application forms should contain brief curriculum vitae, certificate of musical qualification, letter of recommendation from a prominent musical personality, two recent photographs and a copy receipt about the transfer of the entry fee. For competitors outside Europe, a certificate of their European studies is required

Closing Date: 1 February

Funding: Private

Contributor: Philharmonia Budapest Concert Agency and Ms. Fejes Music Foundation

Additional Information: Special prizes will be offered to the winners

For further information contact:

Fax: (36) 13024962

\section{Bupa Foundation}

Bupa House, 15-19 Bloomsbury Way, London, WC1A 2BA, United Kingdom.

Tel: $\quad$ (44) 2076562591

Email: Bupafoundation@Bupa.com

Website: www.bupafoundation.co.uk

Contact: Lee Saunders, Registrar 
The Bupa Foundation is an independent medical research charity that funds medical research to prevent, relieve and cure sickness and ill health.

\section{Bupa Foundation Annual Specialist Grant}

Eligibility: The competition is open to those based in the United Kingdom, Australia, Denmark, Hong Kong, New Zealand, Saudi Arabia, Spain and Thailand. Entries must be compliant with the local health and safety legislation if applicable. The Foundation will seek peer reviews from the home country of each shortlisted entry. Researchers and health professionals working for public or private organisations may apply for Bupa Foundation specialist grants for United Kingdom-based projects.

\section{For further information contact:}

Tel: (36) 2076562591

Email: bupafoundation@bupa.com

\section{Bupa Foundation Medical Research Grant for Health at Work}

Purpose: To support research into the feasibility and potential value of workplace conditions for health promotion and active management of employee health

Eligibility: Open to health professionals and health researchers

Level of Study: Doctorate, Postdoctorate, Postgraduate, Research

Value: Restricted by project need only

Length of Study: A maximum of 3 years

Country of Study: United Kingdom

Application Procedure: For all queries contact Lee Saunders, the Foundation's Registrar

Funding: Foundation

For further information contact:

Email: bupafoundation@bupa.com

\section{Bupa Foundation Medical Research Grant for Information and Communication}

Purpose: To support research designed to enhance partnership between health professionals and public/patients

Eligibility: Open to health professional and health researchers

Level of Study: Doctorate, Postdoctorate, Postgraduate, Research
Value: Restricted by project needs only

Length of Study: Maximum of 3 years

Country of Study: United Kingdom

Application Procedure: For all queries contact Lee Saunders, the Foundation's Registrar

Funding: Foundation

\section{For further information contact:}

Email: bupafoundation@bupa.com

\section{Brandeis University}

Brandeis University was founded in 1948 by the American Jewish community at a time when Jews and other ethnic and racial minorities, and women, faced discrimination in higher education. Brandeis' visionary founders established a nonsectarian research university that welcomed talented faculty and students of all backgrounds and beliefs. From the outset, Brandeis focused on undergraduate education, while building a pioneering research enterprise.

Tel: $\quad$ (1) 7817362000

Email: helleradmissions@brandeis.edu

Website: www.brandeis.edu/

Contact: 415 South Street, Waltham, MA 02453, United

States of America

\section{Sidney Topol Fellowship in Nonviolence Practice}

Purpose: Practice honors the work of peace advocate, philanthropist, and entrepreneur, Sidney Topol, through the establishment of a full tuition scholarship to the Master's Degree program in Coexistence and Conflict (COEX) at the Heller School for Social Policy and Management at Brandeis University. This fellowship does not cover airfare, fees, health insurance, or housing. The Master's Degree in Coexistence and Conflict at Brandeis University trains students to recognize, understand and begin to heal the ethnic, religious and cultural fault lines that endanger our world. Through an approach that is equal parts theoretical and practical, graduate students investigate the root causes of violent conflict and they uncover effective means to prevent conflicts and to promote peaceful coexistence After a full year in residence at the Heller School, students take their knowledge into the field, working with a conflict prevention organization. They graduate with a firm grasp of the delicate role that peace professionals play in bringing antagonistic parties together and the leadership expertise to help communities build shared societies. 
Eligibility: Applicants for the Sidney Topol Fellowship in Nonviolence Practice must prove that their community benefited from their personal commitment to nonviolent principles through prior volunteer or work projects and they must commit to returning to their community within the next 2 years after graduation from the COEX program, to establish projects in nonviolence.

Level of Study: postgraduate

Type: Scholarsip

Value: Full tuition scholarship. This fellowship does not cover airfare, fees, health insurance, or housing

Country of Study: US

Application Procedure: In addition to submitting a complete application to the Coexistence and Conflict program, fellowship applicants must submit the following materials; A personal essay which outlines their prior work in nonviolence, and their proposed work, and how completing the MA in Coexistence and Conflict will help them be successful in these endeavors; An interview either by phone or in person may be required. The deadline for applications for the fellowship is 15 April 2020. It is important to visit the official website (link found below) for detailed information on how to apply for this scholarship : apply.heller.brandeis.edu/register/TopolFellowshipsin Nonviolence

Closing Date: 15 April

Additional Information: apply.heller.brandeis.edu/register/ TopolFellowshipsinNonviolence 